\title{
Decomposing Trends in Educational Homogamy and Heterogamy - The Case of Ireland
}

\author{
Julia Leesch* \\ Department of Sociology, Trinity College Dublin, Ireland \\ and \\ Jan Skopek \\ Department of Sociology, Trinity College Dublin, Ireland
}

Acknowledgments:

We acknowledge the Central Statistics Office, Ireland that provided the underlying data making this research possible. Earlier versions of this article have been presented at conferences of the European Sociological Association (ESA 2021) and the British Society for Population Studies (BSPS 2021). We thank the participants for their feedback.

* Corresponding author. Email: leeschj@tcd.ie

Correspondence address: Trinity College Dublin, Department of Sociology, 3 College Green, Dublin 2, Ireland. 


\begin{abstract}
Although extensive research has examined how partner search behavior and the educational composition of partner markets have changed over time, we lack insight into the extent to which these changes have contributed to trends in educational homogamy. This study analyzed trends in educational homogamy and heterogamy in Ireland over the past three decades. We examined how changes in three components - (a) educational attainment of men and women, (b) the educational gradient in marriage, and (c) educational matching - have contributed to these trends. Based on Irish Census microdata, covering the period from 1991 to 2016, we propose a novel counterfactual decomposition method to estimate the contribution of each component. Findings indicate rising educational homogamy and an increase in non-traditional unions in which women partner 'down' in education, both at the expense of unions in which men are higher educated. Trends in educational homogamy and heterogamy are predominantly attributable to changes in educational attainment of women and men. Trends in the educational marriage gradient also contributed to the rise in homogamy and the decline in traditional unions. Changes in educational matching did not drive trends in homogamy and upward marriage and explained only a small fraction of trends in downward marriage.
\end{abstract}

Keywords: assortative mating, educational gradient in marriage, educational expansion, decomposition, census data 


\section{Introduction}

Assortative marriage outcomes ${ }^{l}$, meaning the level of socioeconomic (dis-)similarity within couples, may have consequences for social inequality and social mobility because they indicate how socioeconomic resources are distributed within and between couples (Blossfeld, 2009; Breen \& Andersen, 2012; McCall \& Percheski, 2010; McLanahan, 2004; Schwartz \& Mare, 2005). Socioeconomic homo- and heterogamy shapes gender inequality because, at the couple level, socioeconomic resources (e.g., education and income) determine spouses' relative power, e.g., in bargaining about division of labor. Since husbands and wives tend to pool their advantageous and disadvantageous socioeconomic resources, homo- and heterogamy outcomes may contribute to intragenerational inequality between households but also to intergenerational inequality as children's socioeconomic attainment depends on parents' socioeconomic resources.

Hence, examining trends in assortative marriage is of crucial importance for understanding trends in social inequality. This study focuses on examining and explaining trends in assortative marriage along lines of educational attainment. Educational attainment is one of the most important predictors of socioeconomic attainment, hence, studying trends in educational homo- and heterogamy is decisive to better understand changes in intra- and intergenerational inequality.

When examining trends in assortative mating, previous research routinely investigated trends in odds ratios as a margin-free measure for spousal associations (e.g. Kalmijn 1991; Schwartz and Mare 2005; Smits 2003). Because marginal distributions of marriage tables have been assumed to measure education compositions of partner markets, odds ratios served as an indicator for trends in assortative mating net of changes

\footnotetext{
${ }^{1}$ Note that we analyse cohabiting couples regardless of whether they are formally married or not. To improve readability, we use the terms marriage, partnership and unions interchangeably.
} 
in structural opportunities and constraints on the partner market. We refer to this marginsfree measure of spousal associations as educational matching. However, it is a methodological shortcoming that these studies cannot quantify the contribution of trends in matching to changes in overall marriage outcomes.

To our knowledge, only one study directly investigated the degree to which trends in educational matching contributed to trends in marriage outcomes. Permanyer et al. (2019) decomposed trends in educational homogamy in terms of college and non-college education in three components - the level of college education, the gender gap in education and educational matching. Their findings indicate that trends in educational matching and the gender gap in education hardly contributed to the rise in homogamy. Instead, they identified the rise in college education as the primary driver of trends in educational homogamy.

One major drawback of Permanyer et al.'s (2019) study and most previous studies on assortative mating is the analytical restriction to (married) couples (Blossfeld, 2009). Consequently, previous research routinely neglects the demographic fact that the process of entering unions is not random but a function of educational attainment too. For women in several western countries, including Ireland, the educational gradient in marriage and union formation has reversed (Bertrand et al., 2020; Goldstein \& Kenney, 2001; Lundberg et al., 2016). In these countries, higher educated women are now more likely to be married or cohabiting than lower educated women. Such a shift in the educational gradient of marriage and union formation shapes the distribution of educational attainment of married and partnered women and men and, therefore, presumably also marriage outcomes. For example, if more partnered women are highly educated, we expect fewer couples in which women are lower educated than their partners. Yet, it is 
still unclear to what extent the changing educational gradient in marriage and union formation drives marriage outcomes.

For the case of Ireland, our study aims to address aforementioned gaps in research by addressing the following two questions: (1) How have marriage outcomes of young adults been changing over time? (2) What is the role of women's and men's educational attainment, the educational gradient in marriage and union formation, and educational matching in explaining those changes?

This study contributes to previous research in several ways. We suggest a novel decomposition technique for isolating the drivers of trends in marriage outcomes. For applying the method we used highly representative and large microdata samples from Irish censuses (Minnesota Population Center, 2020), covering the period from 1991 to 2016. To our knowledge, this is the first study that quantifies the contribution of the educational gradient in marriage to trends in marriage outcomes. Moreover, our study is the first study examining recent trends in marriage patterns in Ireland which represents an interesting case due to its massive educational expansion over the past three decades.

\section{Theoretical Background}

Partner search theory (England \& Farkas, 1986; Oppenheimer, 1988) assumes that marriage outcomes depend on three factors: women's and men's preferences for candidates with specific traits, the availability of candidates with preferred traits on the partner market and on partner search strategies that include, for example, postponing marriage and cohabitation in reaction to a lack of preferred candidates. 


\section{Preferences}

According to Becker's (1981) economic approach to marriage, positive assortative mating along education is expected to the degree that education is a cultural good related to attitudes, values and lifestyle where the educational levels of partners complement each other. However, negative assortative mating along education is expected to the degree that education is related to labor market productivity and, thus, specialization gains from marriage are highest if individuals with high market productivity marry individuals with high household productivity.

As female labor force participation has increased and dual-earner couples became the new norm, scholars expected convergence in women's and men's preference for education. Husbands increasingly benefited from the education of their wives since educated women have better earnings prospects (Mare, 1991). For women, education remains a desirable trait, but the growth in their employment resulted in declining dependency on male education and earnings, which gives them the freedom to choose a partner who offers other desirable traits (Oppenheimer, 1994). Thus, the benefits of positive assortative mating may increasingly outweigh the specialization gains from negative assortative mating.

Several empirical results suggest a declining gap in women's and men's preferences for education. Gender differences in partner preferences have been converging over time (Bech-Sørensen \& Pollet, 2016; Buss et al., 2001) and were found to be smaller in genderegalitarian contexts (Zentner \& Mitura, 2012). Declines in union formation and marriage rates among low educated women in gender-egalitarian countries (Bertrand et al., 2020; Goldstein \& Kenney, 2001; Kalmijn, 2013) could indicate that men developed a preference for higher educated women. We expect that converging preferences for 
education contributed to declines in women partnering up in education and, therefore, a rising proportion of women with an equally or lower-educated partner.

\section{Partner Market}

Opportunity structures matter as the size of a group indicates the likelihood of meeting a member of this group (Blau, 1977; Blau et al., 1982). Hence, the educational structure of the partner market shapes marriage outcomes - the larger an educational group, the higher the probability of meeting and marrying a member of this group. Several studies have supported the hypothesis that the partner market composition in the population (Blau et al., 1982; Blum, 1985) and local partner markets (Lewis \& Oppenheimer, 2000) is linked to marriage outcomes.

The expansion of higher education changed the size of educational groups profoundly. While shifting from predominantly low to predominantly high levels of education, the variation in educational levels followed most likely an inverted U-shape pattern. The small variation in education that occurs at the beginning and the end of the educational expansion facilitates higher levels of homogamy and restrains heterogamous matching. The upgrade of partnered women's and men's educational attainment was found to be the key driver of trends in educational homogamy (Katrňák \& Manea, 2020; Permanyer et al., 2019). We expect that the decline in educational variation that took place over the last decades in Ireland contributed to declining heterogamy and rising homogamy.

The gender gap in education shapes the educational composition of the partner market too. In almost all countries worldwide, women's educational attainment has been rising faster than men's (Esteve et al., 2016), and in most European countries, this 
resulted in a reversed gender gap in education (De Hauw et al., 2017; Esteve et al., 2016). If matching were at random, the absence of a gender gap in education would be associated with a high probability of meeting equally educated candidates and, therefore, high levels of homogamy. The development of a female educational advantage is expected to contribute to more women marrying down in education. By analyzing partnered women and men, Esteve et al. (2016) show a macro-level association between the reversing gender gap in education and the increase in women marrying down in education. Yet, Permanyer et al. (2019) find that the reversing gender gap in education hardly counteracted the rise in educational homogamy.

\section{Partner Search}

The structuralist perspective on the relationship between the partner market and marriage outcomes is, however, insufficient because it ignores how individuals react to partner market constraints. For example, even if a shortage of preferred candidates exists, individuals do not have to settle for someone who cannot meet their expectations. Instead, they could choose to postpone union formation, hoping to meet a better partner in future (De Hauw et al., 2017; Oppenheimer, 1988). Thus, the reversing gender gap in education and the size of educational groups change not only meeting opportunities but also how individuals may adapt their partner search to these changing structural constraints.

There are three possible pathways to being unpartnered. First, individuals may choose not to marry regardless of their options on the partner market. Second, someone may want to marry, but available candidates on the partner market do not meet their aspiration level. For example, if women were reluctant to marry lower educated men, the reversal of the gender gap in education could be linked to declining marriage rates for highly 
educated women. Third, individuals who aspire to marry may remain unmarried if the demand for their own traits is too low. Convergence in women's and men's preference for education would suggest a declining demand for low educated women and highly educated men and, thus, declining marriage rates in these groups. In contrast, Oppenheimer (1988) suggests that stable work is a signal for the future socioeconomic status that is required in the partner search process and for partnership-specific investments such as setting up a joint household. Low educated men and women who increasingly experience precarious employment may fail to provide certainty about their work career. The declining demand of low educated men and women would lead to falling marriage rates among the lower educated.

In particular, in countries where the current gender roles are egalitarian, research points towards the latter explanation. In these countries, women's educational gradient in marriage and union formation had reversed (Bertrand et al., 2020; Goldstein \& Kenney, 2001; Kalmijn, 2013; Torr, 2011). That means, in the past, highly educated women had lower marriage rates than low educated women, whereas now, highly educated women have higher marriage rates than low educated women. In Ireland, this pattern has been observed too (Bertrand et al., 2020). Moreover, the disadvantage lower educated men experienced in terms of marriage rates has intensified in many western countries over the last decades (Bertrand et al., 2016).

Regardless of the mechanisms that caused the shift in the marriage gradient, the changing gradient can shape trends in marriage outcomes. Because marriage rates of low educated men and women have been declining, the married population is on average higher educated than the group of all (married and unmarried) individuals. We expect 
that the resulting increase in educational similarity of married men and women is a driver of rising educational homogamy.

The link between the marriage gradient and marriage outcomes also depends on how the marriage gradient has shaped the gender gap in education of married women and men. For example, if the change in the marriage gradient had been more pronounced for women, the educational level of married women would have increased more than the one of married men. This may reinforce the reverse of the gender gap in education in the partnered population. We expect that this would be linked to a rise in women partnering down in education at the expense of a decline in women with an equally or lower educated partner.

\section{The Context of Ireland}

The social changes we discussed as potential causes of changing marriage outcomes are particularly pronounced in Ireland compared to other European countries. The labor force participation and employment of Irish women have risen sharply in recent decades (Bercholz \& FitzGerald, 2016; Thévenon, 2013). In 1980, women's employment in the prime working-age of 25 to 54 was with below $30 \%$ far below the OECD average of $54 \%$. Afterwards, women's employment increased rapidly and almost met the OCED average of $71 \%$ in 2010 (Thévenon, 2013). The remarkable growth in female employment indicates a rising contribution of women's earnings to household incomes.

The Irish educational expansion has also been considerably stronger than in other OECD countries. Among 25 to 34-year-old men and women, tertiary education has risen rapidly from 14\% in 1996 to $70 \%$ in 2019 (OECD, 1999, 2020). Within this age group, Ireland has been the OECD country with the most substantial growth in tertiary education 
over the last decade - the share of tertiary education has risen by over $20 \%$ (OECD, 2020). Because women's education has been growing faster than men's, from the mid1990s onwards, more Irish women than men were enrolled in tertiary education (De Hauw et al., 2017; Vincent-Lancrin, 2008).

Moreover, Bertrand et al. (2020) found that among the European countries where the educational gradient in women's union formation has reversed, the difference in marriage rates between high and low educated women is the largest in Ireland. The fact that the social changes we are interested in are exceptionally pronounced in Ireland shows that the Irish case is well suited for studying the consequences of these changes for marriage outcomes.

\section{Data}

\section{Sample}

Our analysis is based on data from the "International Public Use Microdata Series, International" (IPUMS-I). IPUMS-I provides samples of harmonized census data. For our analysis, we used 10\% samples from the Irish censuses of 1991, 1996, 2002, 2006, 2011 and 2016 which provides the study with highly representative data. Sample sizes are large, and the samples do not suffer from sampling bias since they were drawn from full population data.

We restricted the sample to 25- to 34-year-old women of the de facto population. The age group is theoretically relevant because at this age young women complete the transition to adulthood and lay the foundation for family life. By age 25, most women have finished their education, and they are in the process of establishing their careers. This reduces uncertainties in the partner search by increasing the predictability of future 
socioeconomic attainment. At the same time, the age before 35 is critical for childbearing, as women's fecundity and the socially accepted age for childbearing drop rapidly between the age of 35 and 50 (Billari et al., 2011; Leridon, 2004).

In addition, the small age interval of ten years is advantageous for analyzing betweencohort trends as the cohort overlap is minimized. Excluding women older than 34 reduces the effect of assortative union dissolution, remarriage and educational upgrades within marriages on the results (Permanyer et al., 2019; Schwartz \& Mare, 2012). However, since women's age at first marriage has been increasing (Central Statistics Office, 2015, 2021), marriage outcomes in this age group also reflect trends in the timing of marriage and union formation.

We analyzed 'marriage outcomes' of women in cohabiting unions regardless of whether they are formally married or not because trends in educational homogamy and heterogamy can have consequences for social mobility and inequality irrespective of the marriage status. Just as married couples, unmarried cohabitors have children (Kiernan, 2001), they profit from the economy of scale and, although to a lesser extent than married couples, they pool their income (Hiekel et al., 2014).

We deleted cases of women who have a partner who lives in another household because, in this case, information about the partner's education is not available. Subsequently, cases were deleted list-wisely if a woman's or their partner's education was missing. In all samples, the fraction of missing values is below $6 \%$. Table B1 in the Appendix depicts case numbers by census year at each stage of the sample selection after subtracting the indicated cases.

For the decomposition analysis, we created contingency tables that show marriage outcomes and the educational gradient in marriage (Tables B6 - B11, Appendix). The 
initial table indicates women's educational level, whether they have a partner, and if so, what educational level he has. Next, we approximated the number of unmarried men by census year and educational attainment which is necessary for assessing the role of changes in the educational gradient of union formation. Based on a matching sample of men $^{2}$, we calculated the ratio of unmarried and married men in each census year and educational category. For estimating the number of unmarried men, we multiplied this ratio with the number of men who are married to the women in our sample.

\section{Measures}

Our measure for education aims to differentiate between the socioeconomic consequences associated with different educational attainment levels, such as income and career prospects (Blossfeld \& Timm, 2017). That is necessary because the socioeconomic consequences of education have been assumed to be a reason why education matters in the partner search.

Our measure is based on the International Standard Classification of Education (ISCED-11) (UNESCO 2012). We collapsed the nine-level scale into a classification of four categories which is widely used for distinguishing between educational levels in Ireland (e.g. Halpin \& Chan, 2003; Whelan \& Layte, 2002). The scale differentiates between primary or less, lower secondary, higher secondary and tertiary education. Tertiary education (ISCED 5 and higher) is equivalent to any tertiary degree. Higher secondary education (ISCED 3 and 4) indicates that secondary education was completed

\footnotetext{
2 Throughout the observation period husbands are on average two years older than their wife (Central Statistics Office, 2015, 2021). Thus, 27- to 36-year-old men approximate the marriage market of 25 to 34-year-old women. Because data on age is provided in five-year categories, we approximated the group of 27 - to 36 -year-old men with all 30- to 34-year-old men, $60 \%$ of 25 - to 29 -year-old men and $40 \%$ of 35- to 39-year-old men.
} 
with the Leaving Certificate. Lower secondary education (ISCED 2) is equivalent to the Junior, Group, or Intermediate Certificate. Lower qualifications (secondary education without any qualifications, primary education, less than primary education) fall into the "primary or less" (ISCED 0 and 1) category.

We believe that our measure discriminates well between socioeconomic differences not only because it reflects the Irish educational system, i.e., the educational degrees that can be obtained upon completing a cycle in the education system, but also because it reflects differences in the returns to education. McGuinness et al. (2009) found that returns to education differ substantially between these four categories. Moreover, they found differences in returns to education between different levels of tertiary education. Because our data does not allow us to differentiate between levels of tertiary education, the four-level scale is the best possible representation of educational differences in Ireland.

\section{Methods}

Our analysis, first, examines trends in marriage outcomes based on year-specific marriage tables. Second, we employ a novel decomposition method to estimate how changing educational distributions, marriage gradients, and matching processes have contributed to changing marriage tables. In the following, we introduce the basic elements and steps of our decomposition approach but provide more details and a numerical example in the Appendix. 


\section{Marriage Table and Marriage Outcomes}

In the first part of our analysis, we investigate how marriage outcomes have been changing over time. Analyzed are trends in the proportion of married women who are married either to an equally, higher, or lower-educated man. To calculate outcomes, we sum entries in a marriage table, represented by a $K \times K$ matrix that contains the relative joint distribution of wives' and their husbands' education:

$$
\boldsymbol{M}_{t}=\left[\begin{array}{ccc}
m_{11} & \ldots & m_{1 K} \\
\ldots & \ddots & \ldots \\
m_{K 1} & \ldots & m_{K K}
\end{array}\right]
$$

In our case, $K=4$ since we have four educational categories. Index $t$ denotes the year of the census. A table cell (or matrix element) $m_{i j}$ is the fraction of marriages that involve a wife with education level $i$ and a husband with educational level $j$. Hence, all cells sum up to 1 .

Marriage outcome $Y$ at time $t$ is a scalar function of $\boldsymbol{M}_{t}$ :

$$
Y_{t}=f\left(\boldsymbol{M}_{t}\right)
$$

For example, the probability of homogamy (spouses have the same education) is just the sum over the diagonal of $\boldsymbol{M}_{t}$ :

$$
Y^{W=H}\left(\boldsymbol{M}_{t}\right)=\sum_{k=1}^{K} m_{i=k, j=k}
$$


Accordingly, the probability of female hypergamy (wives married upward) is the sum of the upper off-diagonals

$$
Y^{W<H}\left(\boldsymbol{M}_{t}\right)=\sum_{k=1}^{K-1} \sum_{l=k+1}^{K} m_{i=k, j=l}
$$

and the probability of female hypogamy (wives married downward) is the sum of the lower off-diagonals

$$
Y^{W>H}\left(\boldsymbol{M}_{t}\right)=\sum_{k=2}^{K} \sum_{l=1}^{k-1} m_{i=k, j=l}
$$

In total, we constructed six marriage tables, $\boldsymbol{M}_{1}$ to $\boldsymbol{M}_{6}$ corresponding to census years 1991 to 2016 and calculated all three outcomes for each table. The data tables B6 - B11 in the Appendix include the information of the six marriage tables and the number of unmarried men and women by education. Point of reference for evaluating trends in outcomes is the first time point or table $\boldsymbol{M}_{1}$.

\section{Decomposing Trends in Marriage Outcomes}

The primary aim of our study is to get a better understanding of the structural forces that drive trends in marriage outcomes in Ireland. For that purpose, the second step of the analysis will decompose differences between marriage outcomes in years with regard to the reference year 1991, for example, the difference in homogamy levels between 1991 $(t=1)$ and $2016(t=2)$, that is $Y_{2}^{W=H}-Y_{1}^{W=H}$. In line with our conceptual discussion, 
we are asking how much of those observed differences are attributable to (1) educational expansion in men and women (i.e., changing educational distributions), (2) changing probabilities of being married by education level (i.e., changing marriage gradients), and (3) changing educational matching preferences and choices (i.e., the changing educational association among married men and women).

We propose a decomposition technique that builds on the insight that cells in a marriage table can be recovered solely from the table's marginal distributions (the educational distributions of husbands and wives respectively) and the table's odds ratio structure (reflecting the nature and degree of association between husband's and wife's education) via iterative proportional fitting (IPF) (Deming \& Stephan, 1940). IPF is a widely used algorithmic procedure that allows adjusting cells in one table to row and column totals (marginals) of another table without changing the odds ratio structure of the initial table (e.g., see Lomax and Norman 2016).

\section{Dissecting the Marriage Table}

Marginals and odds ratios capture different mechanisms driving marriage outcomes. In our context, the marginals of the marriage table represent the supply of men and women in different education categories among those who marry. These opportunity structures influence the probability of certain marriage outcomes and might explain why they change. For example, if women are increasingly higher educated when they marry (thereby becoming educational more similar to men who marry) the structural probability of homogamous marriages increases. In our formalization, wives' educational distribution is given by row sum of $\boldsymbol{M}_{t}$ and husbands' distribution by the column sum: 


$$
\boldsymbol{E}_{t}^{W}=\left[\begin{array}{c}
m_{1}=\sum_{k}^{K} m_{1 k} \\
\cdots \\
m_{K} \cdot=\sum_{k}^{K} m_{K k}
\end{array}\right], \boldsymbol{E}_{t}^{H}=\left[m_{.1}=\sum_{k}^{K} m_{k 1} \quad \ldots \quad m_{. K}=\sum_{k}^{K} m_{k K}\right]
$$

Odds ratios are margin-free measures of a categorical association. They measure the association structure within the table and, therefore, the joint distribution's departure from the distribution under independence, a hypothetical distribution expected to be realized if husbands and wives would match randomly along the lines of education. Past research frequently has interpreted odds ratios as matching 'preferences' emphasizing the fact that men and women are actors who make non-random choices about their partners within given opportunities. ${ }^{3}$ In our case, the odds ratio represent the ratio between $i$-educated women's probability to marry a $j$-educated husband over marrying a l-educated husband (odds of a $j$-husband) and 1 -women's odds of marrying $j$-husbands. For the general case of $K>2$ (we have $K=4$ ), we derive from $\boldsymbol{M}_{t}$ the matrix of odds ratios (of dimension $K \times K$ ):

\footnotetext{
${ }^{3}$ The practice of referring to odds ratios as measures for preferences has been criticised in the literature (Logan et al., 2008; Permanyer et al., 2019). We would like to highlight that our use of odds ratios does not intend to measure mating preferences. Rather we capture the matching process which involves various mechanisms on the meso and the micro level such as regional or local marriage market opportunities, individual mating preferences, and the process of two-sided matching.
} 


$$
\boldsymbol{O} \boldsymbol{R}_{t}=\left[\begin{array}{cccc}
1 & 1 & \cdots & 1 \\
1 & \frac{m_{22}}{m_{21}} / m_{12} & \cdots & \frac{m_{2 K}}{m_{21}} / \frac{m_{1 K}}{m_{11}} \\
\cdots & \cdots & \ddots & \cdots \\
1 & \frac{m_{K 2}}{m_{K 1}} / m_{12} & \cdots & \frac{m_{K K}}{m_{K 1}} / m_{1 K} \\
& / \frac{m_{11}}{m_{11}} & &
\end{array}\right]
$$

In that respect, we define $M($.$) being an iterative proportional fitting (with x$ iterations) operation that takes the odds-ratio matrix on the one hand and row and column totals on the other hand as inputs to fit the same table's cells. Hence, we rewrite $\boldsymbol{M}_{t}$ as an asymptotic (as $x \rightarrow \infty$ ) IPF function of the marginal row and column vectors and the matrix of odds ratios:

$$
\boldsymbol{M}_{t} \underset{x \rightarrow \infty}{=} M\left(\boldsymbol{E}_{t}^{W}, \boldsymbol{E}_{t}^{H}, \boldsymbol{O} \boldsymbol{R}_{t}\right)
$$

\section{Two-Fold Decomposition: Opportunities and Matching}

Both mechanisms, two-sided matching preferences, and opportunities to marry shape assortative marriage patterns, but both have changed from time $t=1$ (e.g., year 1991) to time $t=2$ (e.g., year 2016). To better understand changes in marriage patterns, our analysis proposes to isolate the potential influence of either mechanism on the observed changes. Illustrated for homogamy, we ask hypothetical questions: How much homogamy would we have observed at Time 2 if only opportunities but not preferences had changed from Time 1 to Time 2? And, vice versa, how large were homogamy at Time 2 if only preference but not opportunities had changed? Hence, our approach to isolate the influence of choices and opportunities involves calculating counterfactual 
homogamy outcomes $(\dot{Y})$ and comparing them with the actual homogamy outcomes observed $(Y)$. Table B2 in the Appendix summarizes observed and counterfactual homogamy outcomes.

Based on the IPF function from above, counterfactuals are defined as hypothetical tables that we would observe if opportunities and matching preferences were swapped:

$$
\dot{Y}_{21}=Y\left(M\left(\boldsymbol{E}_{2}^{W}, \boldsymbol{E}_{2}^{H}, \boldsymbol{O} \boldsymbol{R}_{1}\right)\right)
$$

and

$$
\dot{Y}_{12}=Y\left(M\left(\boldsymbol{E}_{1}^{W}, \boldsymbol{E}_{1}^{H}, \boldsymbol{O} \boldsymbol{R}_{2}\right)\right)
$$

Having factual and counterfactual rates allows us to decompose elements of changes in marriage patterns formally. The overall differences between marriage outcomes (e.g., homogamy if $Y$ is the homogamy function) at Time 2 and Time 1 can be written as

$$
Y_{22}-Y_{11}=\left(Y_{22}-\dot{Y}_{12}\right)+\left(\dot{Y}_{12}-Y_{11}\right)
$$

which is the sum of the 'opportunity effect', the hypothetical difference if only opportunities had changed, but preferences were fixed to the level of Time $2\left(Y_{22}-\dot{Y}_{12}\right)$, and the 'preference effect', the hypothetical difference if only preferences had changed, but opportunities were fixed at the level of Time $1\left(\dot{Y}_{12}-Y_{11}\right)$. In the same fashion, we could write 


$$
Y_{22}-Y_{11}=\left(\dot{Y}_{21}-Y_{11}\right)+\left(Y_{22}-\dot{Y}_{21}\right)
$$

which is the sum of the hypothetical difference if only opportunities had changed but preferences were fixed to the level of Time $1\left(\dot{Y}_{21}-Y_{11}\right)$ and the hypothetical difference if only preferences had changed but opportunities were fixed at the level of Time $2\left(Y_{22}-\right.$ $\left.\dot{Y}_{21}\right)$. Consequently, there are two opportunity and two preferences effects depending on taking Time 1 or Time 2 as reference. Adding (11) and (12) and rearranging terms leads to

$$
Y_{22}-Y_{11}=\frac{1}{2}\left(Y_{22}-\dot{Y}_{12}+\dot{Y}_{21}-Y_{11}\right)+\frac{1}{2}\left(\dot{Y}_{12}-Y_{11}+Y_{22}-\dot{Y}_{21}\right)
$$

Equation (13) expresses the difference in homogamy rates as the sum of two components: the average opportunity effect (first term of Equation 13) and the average preference or choice effect (second term). We generalize the notation by writing

$$
\Delta_{i j}^{T}=\Delta_{i j}^{O}+\Delta_{i j}^{C}
$$

with $\Delta_{i j}^{T}$ denoting the total difference between Time $i$ and $j, \Delta_{i j}^{O}$ the opportunity effect (the difference expected if only opportunities differed between times), and $\Delta_{i j}^{C}$ the 'choice' or preference effect (the difference expected if only preferences differed between times). 


\section{Three-Fold Decomposition: Education Expansion and Changing Marriage Gradient}

Although marginal distributions in the marriage table analytically represent opportunities in the marriage market in much of previous research on assortative mating (e.g. Permanyer et al., 2019; Schwartz \& Mare, 2005; Smits et al., 1998), such a conceptualization is not without problems. Since not all young men and women marry, the marginal distributions of education in the marriage table do not accurately reflect the distribution of education in the actual population that had been at risk of marriage. Consequently, changes in marginal distributions of education (in marriages tables) reflect both changing educational distributions in the overall population and changing education-specific propensities to marry (the educational gradient in marrying). We, therefore, extend the two-fold decomposition by distinguishing two components of opportunities: educational distributions for all men and women and men's and women's education-specific marriage rates (reflecting educational gradients in marriage).

Formally, wives' relative education distributions are the product of women's education distribution and women's education-specific probabilities of being married (marriage rates):

$$
\boldsymbol{E}_{t}^{W}=\boldsymbol{G}_{t}^{F} \boldsymbol{E}_{t}^{F} \cdot \frac{1}{\operatorname{SUM}\left(\boldsymbol{G}_{t}^{F} \boldsymbol{E}_{t}^{F}\right)}
$$

with $\boldsymbol{G}_{\boldsymbol{t}}^{\boldsymbol{F}}$ being a diagonal $K x K$ matrix with elements $g_{i i}$ denoting the probabilities of being married for women with education level $i$ 


$$
\boldsymbol{G}_{t}^{F}=\left[\begin{array}{ccc}
g_{11} & 0 & 0 \\
0 & \ldots & 0 \\
0 & 0 & g_{K K}
\end{array}\right]
$$

and $\boldsymbol{E}_{t}^{F}$ being a $K x 1$ column vector containing the education distribution among women (analogously to the education distribution among wives $\boldsymbol{E}_{t}^{W}$ ). Thus, the product $\boldsymbol{G}_{t}^{F} \boldsymbol{E}_{t}^{F}$ yields a column vector containing the education distribution of married women. To get the relative distribution $\boldsymbol{E}_{t}^{W}$, we divide all vector elements by the number of married women given by $\operatorname{SUM}\left(\boldsymbol{G}_{t}^{F} \boldsymbol{E}_{\boldsymbol{t}}^{\boldsymbol{F}}\right) \cdot{ }^{4}$ Consequently, we can rewrite wives' relative education distribution as a function $E($.$) defined by women's education distribution and marriage$ rates:

$$
\boldsymbol{E}_{t}^{W}=E\left(\boldsymbol{G}_{t}^{F}, \boldsymbol{E}_{t}^{F}\right)
$$

Concerning the education distribution of husbands, we proceed analogously. ${ }^{5}$ Based on that, we redefine the marriage table $t$ as a function of five components

$$
\boldsymbol{M}_{t}=M\left[E\left(\boldsymbol{G}_{t}^{F}, \boldsymbol{E}_{t}^{F}\right), E\left(\boldsymbol{G}_{t}^{M}, \boldsymbol{E}_{t}^{M}\right), \boldsymbol{O} \boldsymbol{R}_{t}\right]
$$

Since we have now three components in the table - education distributions, the marriage gradients, and matching preferences - we can construct $2^{3}=8$ outcomes, two factual and six counterfactual outcomes, extending the previous table (Table A3, Appendix).

\footnotetext{
${ }^{4}$ The operation $\operatorname{SUM}($.$) generates the sum of the matrix elements, which is a scalar.$

5 Because husbands' education distribution is a row vector, we have $\boldsymbol{E}_{t}^{H}=\boldsymbol{E}_{t}^{M} \boldsymbol{G}_{t}^{M} \cdot \frac{1}{\operatorname{SUM}\left(\boldsymbol{E}_{t}^{M} \boldsymbol{G}_{t}^{M}\right)}$ accordingly.
} 
In line with Equation 13 (see above), we write the difference in marriage outcomes at Time 1 and 2 as the sum of the average opportunity and preferences effect:

$$
\begin{aligned}
Y_{222}-Y_{111}= & \frac{1}{2}\left(Y_{222}-\dot{Y}_{112}+\dot{Y}_{221}-Y_{111}\right) \\
& +\frac{1}{2}\left(\dot{Y}_{112}-Y_{111}+Y_{222}-\dot{Y}_{221}\right)
\end{aligned}
$$

Now, the opportunity effects can be further disentangled into an 'educational expansion' effect and a 'marriage gradient' effect. The first part of the opportunity effect is

$$
Y_{222}-\dot{Y}_{112}=Y_{222}-\dot{Y}_{122}+\dot{Y}_{122}-\dot{Y}_{112}
$$

and

$$
Y_{222}-\dot{Y}_{112}=\dot{Y}_{212}-\dot{Y}_{112}+Y_{222}-\dot{Y}_{212}
$$

and combined

$$
Y_{222}-\dot{Y}_{112}
$$




$$
\begin{gathered}
=\frac{1}{2}\left(Y_{222}-\dot{Y}_{122}+\dot{Y}_{122}-\dot{Y}_{112}+\dot{Y}_{212}-\dot{Y}_{112}+Y_{222}-\dot{Y}_{212}\right) \\
=\underbrace{\frac{1}{2}\left(Y_{222}-\dot{Y}_{122}+\dot{Y}_{212}-\dot{Y}_{112}\right)}_{\text {educational expansion }} \\
+\underbrace{\frac{1}{2}\left(\dot{Y}_{122}-\dot{Y}_{112}+Y_{222}-\dot{Y}_{212}\right)}_{\text {marriage gradient }}
\end{gathered}
$$

Accordingly, the second part is

$$
\dot{Y}_{221}-Y_{111}=\dot{Y}_{221}-\dot{Y}_{121}+\dot{Y}_{121}-Y_{111}
$$

and

$$
\dot{Y}_{221}-Y_{111}=\dot{Y}_{211}-Y_{111}+\dot{Y}_{221}-\dot{Y}_{211}
$$

and combined

$$
\begin{aligned}
\dot{Y}_{221}-Y_{111}= & \underbrace{\frac{1}{2}\left(\dot{Y}_{221}-\dot{Y}_{121}+\dot{Y}_{211}-Y_{111}\right)}_{\text {educational expansion }} \\
& +\underbrace{\frac{1}{2}\left(\dot{Y}_{121}-Y_{111}+\dot{Y}_{221}-\dot{Y}_{211}\right)}_{\text {marriage gradient }}
\end{aligned}
$$

Hence, the overall opportunity effect is composed of two sub-components, the average educational expansion effect and the average marriage gradient effect. 


$$
\begin{aligned}
&\Delta^{O}=\underbrace{\frac{1}{2}\left(Y_{222}-\right.}_{\text {Opportunity }} \dot{Y}_{112}+\dot{Y}_{221}-Y_{111}) \\
&=\underbrace{\frac{1}{4}\left(Y_{222}-\dot{Y}_{122}+\dot{Y}_{212}-\dot{Y}_{112}+\dot{Y}_{221}-\dot{Y}_{121}+\dot{Y}_{211}-Y_{111}\right)}_{\text {educational expansion } \Delta^{E}} \\
&+\underbrace{\frac{1}{4}\left(\dot{Y}_{122}-\dot{Y}_{112}+Y_{222}-\dot{Y}_{212}+\dot{Y}_{121}-Y_{111}+\dot{Y}_{221}-\dot{Y}_{211}\right)}_{\text {marriage gradient } \Delta^{G}}
\end{aligned}
$$

Finally, we arrive at the threefold decomposition model:

$$
\Delta_{i j}^{T}=\Delta_{i j}^{O}+\Delta_{i j}^{C}=\Delta_{i j}^{E}+\Delta_{i j}^{G}+\Delta_{i j}^{C}
$$

We conducted pairwise decomposition analyses for each census year from 1996 to 2016 compared to the first observation in 1991. Moreover, Tables B12 to B23 in the Appendix show all pairwise comparisons. We applied the same methodology for decomposing trends in homogamy and trends in women marrying up and down in education. In addition, the Appendix provides a numerical example to illustrate the decomposition and its interpretation.

\section{Results}

\section{Marriage Outcomes}

Figure 1 shows trends in women's marriage outcomes. Recall that our analysis considers legal marriage and cohabitation. Thus, we use the terms union, partnership and marriage 
interchangeably. The share of women in homogamous unions has been rising slightly from $54.4 \%$ in 1991 to $59.5 \%$ in 2016 . The share of women partnering down in education had risen from $26.5 \%$ in 1991 to $31.0 \%$ in 2011 , followed by a decline to $29.7 \%$ in 2016 . Accordingly, the percentage of 'traditional marriages', i.e., women marrying up in education, has been declining considerably. In 1991 roughly one out of five unions featured such a 'traditional' pattern. However, in 2016, this was true for just one out of ten unions. Taken together, within our 25 years window of observation, we see a rise of homogamous and 'untraditional' unions and a steady crowding out of 'traditional' unions.

\section{$===$ FIGURE 1 ===}

\section{Educational Expansion}

Figure 2 illustrates time trends in educational attainment among young Irish women (age group 25-34) as well as the matched population of men (age group 27-36). The numbers illustrate the substantial educational expansion Ireland has witnessed over the last three decades. In 1991, most women and men had higher secondary education, and all educational groups were represented with at least $10 \%$. Just 25 years later, this has changed drastically, especially for women. The share of tertiary-educated women more than quadrupled by growing from $12 \%$ to $51 \%$, and educational degrees below higher secondary education became very rare. Less than $10 \%$ had an educational degree below higher secondary education in 2016.

Educational expansion was less pronounced among the matched population of men although still showing a remarkable change. Throughout the 25-years window, higher 
secondary education made the largest share of about 40-50\%. Like for women, the share of men attaining lower secondary education or less has been declining substantially. Among men, tertiary education more than tripled rising from $12 \%$ in 1991 to $39 \%$ in 2016.

The expansion in educational attainment is accompanied by an increase in educational concentration at the upper end of the educational spectrum. One way to express concentration is by calculating the dissimilarity index (dashed line in the figure) which indicates the fraction of cases that need to be redistributed to achieve an equal distribution in which each educational category is represented by an equal share. ${ }^{6}$ Figure 2 reveals, for both men's and women's educational distributions, a rising departure from equal distribution, which underlines the rising concentration of educational degrees. As a result, meeting opportunities between ever higher and, therefore, equally educated men and women are enlarging which should foster homogamous marriages.

To explore trends in meeting opportunities further, we evaluated gender gaps in educational levels. Figure 3 plots trends in sex ratios, standardized for the samples of men and women per year, at each educational level. A sex ratio below 1 indicates a surplus of men, values above 1 show a surplus of women. In 1991, women already had an educational edge. The sex ratio for higher secondary and tertiary education was above 1 and for lower educational attainment below 1. Thus, for women, the structural probability of meeting lower educated men was higher than meeting equally or higher

\footnotetext{
${ }^{6}$ The dissimilarity index is defined as $\mathrm{D}=\frac{1}{2} \sum_{i=1}^{N}\left|\frac{a_{i}}{A}-\frac{b_{i}}{A}\right|$, where $a_{i}$ is the number of individuals in with the educational level $i$, A is the number of all individuals and $b_{i}$ is the hypothetical number of individuals in with the educational level $i$ if educational attainment were distributed equally across all educational levels $i$.
} 
educated men. Up to 2011, this gender imbalance in educational attainment had been rising. We observe growth in the ratio of tertiary-educated women to men and declining ratios of women to men in lower educational levels. Hence, the shortage of equally educated men had been growing for tertiary-educated women while lower educated women experienced an increasing surplus of equally educated men. From 2011 to 2016, sex ratios have been either constant or reversing.

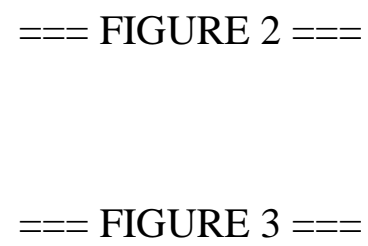

\section{Marriage Gradient}

The educational marriage gradient had reversed for women and men (Figure 4). Although various mechanisms may have contributed to trends in the educational marriage gradient (i.e., postponement, forgoing or dissolution of unions), the figure provides a snapshot of how marriage is structured by education that is required for our analysis. In 1991, the share of married women was the lowest among tertiary-educated women, but between 2002 and 2011, it had risen substantially from $43.8 \%$ to $53.8 \%$. Among women with higher secondary education, the share of married women has changed little. There have been substantial declines in marriage rates for lower-educated women, which levelled off in 2011 for women with lower secondary education and bounced back since 2006 for women with primary or less education. For men, we find similar patterns, however, they are less pronounced. 


\section{$===$ FIGURE 4 ===}

\section{Educational Matching}

Figure 5 shows trends in educational matching which are trends in the 'over-selection' and 'under-selection' into homogamous unions, in marrying down (wife higher educated) or up (husband higher educated) in education. To show these trends we use a log-linear model that controls for changes in educational distributions of husbands and wives. The model measures the ratio by which observed odds of homogamous, upward, and downward marriages differ from odds of a hypothetical model of independence in which marriage outcomes are solely determined by marginal distributions. The dashed line shows trends in educational matching over all educational categories. In general, homogamous unions are more likely than expected under independence and both types of heterogamous unions are less likely than expected under independence.

The overall trend of educational matching into homogamous unions hardly changed over time. However, distinguishing between four educational levels reveals a tendency towards more homogamy among those with lower education and towards less homogamy among the higher educated.

Under-selection into downward marriages is getting substantially smaller after 1996. In recent years, downward marriage is nearly in line with the structural expectation (independence model) for higher secondary educated women and lower secondary educated women even tend to have more downward marriages than predicted by the independence model. The tendency of tertiary-educated women to marry down in education had been rising but is still substantially below the structural expectations. 
Under-selection into upward marriage has been further decreasing after 2002. This general trend is consistent for different levels of female education although lower education makes upward marriage for women less likely.

In summary, we find mixed trends in homogamy matching. The chances for having an equally educated partner, net of trends in the marginals, increased at the lower end of the educational spectrum but declined or remained stable at the higher end. Chances of marrying down in education increased and chances of marrying up in education declined across all educational groups.

$$
===\text { FIGURE } 5 \text { === }
$$

\section{Decomposition}

Table 1 presents results from the decomposition analysis on changes in 25-34-year-old women's marriage outcomes. The findings reveal to what extent trends in marriage outcomes (Figure 1 and Table 1) are attributable to changes in educational matching (Figure 5), the educational structure (Figure 2 and Figure 3), and male and female educational gradients of marriage (Figure 4).

The first section of Table 1 shows results for homogamy. We have seen earlier that homogamy has become slightly more prevalent from 1991 (about 54.4\% of women's marriages) to 2016 (about 59.5\%). The table reveals that this rise in homogamy has been predominantly driven by educational expansion. For example, educational expansion accounted for 4.6 percentage points of the $5.1 \%$ increase in homogamy from 1991 to 2016. Since we expect that the growing gender gap in education would counteract the rise in homogamy findings suggest that rather rising concentration in educational degrees 
explains that the education expansion is the main driver of rising homogamy rates. Furthermore, we see that a small share of the rise in homogamy is attributable to changes in the educational gradient in marriage (significant for 2011 and 2016 versus 1991). In 2016, the marriage gradient accounted for 0.64 percentage points of the $5.10 \%$ increase in homogamy. Since we observed a reversing educational gradient in marriage for women and men, the resulting increase in highly educated married men and women may explain the link between the educational marriage gradient and rising homogamy. Matching coefficients are mostly negative which indicates that changes in matching had counteracted the rise in homogamy. However, those coefficients are tiny in magnitude and not statistically significant. From that, we conclude that changing matching preferences were irrelevant for the observed rise in homogamy.

The second section of Table 1 shows trends and decomposition results for the "nontraditional' pattern of women marrying downward in education. All three components contributed to the rise in those non-traditional unions. Nevertheless, like for homogamy, it is educational expansion and associated changes in the distribution of educational attainment that explain the lion's share of that rise. This pattern is most pronounced when comparing 2011 with 1991: about $66 \%(0.0299 / 0.0450=0.664)$ of the overall rise of female downward marriage was explained by educational expansion. A possible reason for the diminishing contribution of trends in the educational structure in 2016 could be the flattening of the gender gap in education, which stopped the growth in the number of highly educated women. Trends in the educational marriage gradient also account for the rise in non-traditional unions. Yet, the gradient effect is only statistically significant for the contrast 2006 versus 1991. Finally, changing matching preferences account for a 
small (significant for 2002 and 2006 versus 1991) rise in women partnering down in education.

Turning to the last outcome, women marrying higher educated men. The third section of Table 1 reveals that distributional changes in education explain most of the decline in those 'traditional' unions (e.g., 77\% of the difference between 2016 and 1991). Two mechanisms may explain the strong link between the changing educational distribution and the decline in women marrying upward. Growing educational variation is linked to better meeting opportunities among equally educated individuals, and the reversing gender gap in education facilitates matching between higher educated women and lower educated men. Trends in the marriage gradient account for a substantial share of the decline in traditional unions (e.g., 19\% for the 2016 vs. 1991 contrast). That suggests that the reversing marriage gradient is linked to a rise in higher educated married women who establish unions with equally lower educated men. The contribution of trends in educational matching is almost nil.

Taken together, our decomposition has demonstrated that trends in marriage outcomes are mainly driven by changes in women's and men's educational attainment. Changing rates of marriage by education (the marriage gradient) explain observed trends in marriage outcomes too, yet to a lesser extent. Finally, we have seen that changes in matching preferences played only a negligible role in shaping marriage outcomes. They do not account for the rise in homogamy and women marrying up in education and for trends in women marrying down in education, they seem not to be a major driver of the observed trends.

\footnotetext{
$===$ TABLE 1 ===
} 


\section{Sensitivity Analyses}

We carried out further analyses to test the sensitivity of the results to alternative sample selections. Since changes in the timing of marriage and union formation may have shaped the results, we replicated the analysis with a sample of 35 to 44-year-old women. Although the share of unpartnered women is substantially smaller in this age group (Figure A4, Appendix), trends in marriage outcomes are similar to those in the younger sample (Figure A1, Appendix). Figures A2 - A4 in the Appendix show descriptive results and Table B4 (Appendix) shows the decomposition analysis that is based on this sample. Overall, we find similar results within this age category. However, the contribution of trends in the educational structure to the rise in non-traditional unions is substantially higher than in the younger sample. This may stem from different trends in the gender gap in education since the reverse of the gender gap is more pronounced than in the older sample (Figure A3, Appendix).

In addition, migration may have contributed to the observed patterns if migrants tend to form unions with each other and their educational attainment differs from the nonmigrant population. To examine if this is the case, we excluded couples of international migrants (that means both partners' previous residence was abroad) from the sample (Table B5, Appendix). We observe similar trends in marriage outcomes although the increase in women marrying down in education is higher and the increase in homogamy is smaller than in the initial sample. Yet, that does not change the main conclusions of the study. Trends in the educational structure are still the main driver of trends in marriage outcomes and trends in the marriage gradient and matching preferences explain only a small extent of the observed trends. 


\section{Discussion}

Our study examined trends in assortative marriage outcomes in Ireland and the structural causes that have been driving those trends. More specifically, we studied to what extent changes in educational matching, the educational structure, and the educational gradient in marriage contributed to the rise in homogamy and women marrying down in education as well as the decline in women marrying up in education. We developed a counterfactual decomposition method that quantifies the relevance of the three components for observed changes in assortative marriage outcomes. We identified educational expansion as the primary driver of trends in marriage outcomes. To a lesser extent, the changing educational gradient in marriage contributed to the observed trends too. Trends in educational matching accounted only for a small component of trends in women marrying down in education, and they did not affect trends in homogamy and upward marriage.

Our results support previous studies in finding that changes in couples' educational similarity are mainly driven by 'structural constraints', i.e. the availability of married men and women in different educational groups, rather than by educational matching (Permanyer et al., 2019). Moreover, this study advances previous findings by demonstrating that the component that has previously been considered corresponding to 'structural constraints' is also shaped by the educational marriage gradient, which contributed slightly to trends in marriage outcomes. We hope further research will analyze the generalizability of our results to other contexts, particularly to countries in which the educational expansion and the marriage gradient developed differently.

The findings of this study have implications for the debate about the consequences of trends in educational matching and marriage outcomes, particularly for the question of 
whether changes in educational homogamy have been large enough to affect macro-level characteristics such as earnings inequality (Breen \& Salazar, 2011; Schwartz, 2013). We found considerable changes in marriage outcomes which may be a driver of such social changes. However, it is unlikely that trends in educational matching are a substantial driver of such consequences since they hardly contributed to trends in marriage outcomes.

The methodology we introduced offers a wide range of applications. It is not only a flexible tool for decomposing differences between two contingency tables (e.g., between years or countries) but also for forecasting macrostructural outcomes which can be relevant for social policy.

When interpreting our results, several limitations should be considered. Due to the cross-sectional nature of the data, the observed trends provide only a snapshot of 'who is married with whom' and 'who is married at all'. Thus, the results may be affected by education-specific changes in postponing or forgoing marriage and in union dissolution.

Our results rely on the assumption that trends in educational matching, the educational structure and the marriage gradient are independent of each other, although this may not reflect reality. For example, the marriage gradient may be affected by the gender gap in education because a reversing gender gap in education could be linked to an increase in highly educated women who postpone union formation. Although our method cannot account for such interdependencies, we believe that an analytical distinction between the drivers of trends in marriage outcomes improves our understanding of the processes that generated these trends.

Although we showed that changes in the educational composition of the marriage market are a key driver of trends in marriage outcomes, it is unclear how much of the 
change is linked to declining educational variation or the reversing gender gap in education. The same holds for trends in the educational marriage gradient since changes in the marriage gradient affect educational variation and the gender gap in education among married men and women. Moreover, it remains unclear how much of the educational marriage gradient is driven by a structural (e.g., postponing union formation due to a limited supply of suitable candidates) and how much by a behavioral component (e.g., postponing union formation because of educational preferences).

The results of our study and most studies on educational assortative mating depend on the chosen educational categories (Gihleb \& Lang, 2016). Since we are not able to distinguish between longer and shorter tertiary degrees, we disregard the relevance of the socioeconomic differences that emerge from these degrees for the partner search process. But even if the chosen educational categories discriminate between socioeconomic differences at one point in time, they may not predict the same socioeconomic differences at another time. Socioeconomic outcomes that are linked to an educational level may have changed over time which can affect the comparability of marriage outcomes across time. 


\section{References}

Bech-Sørensen, J., \& Pollet, T. V. (2016). Sex differences in mate preferences: A replication study, 20 years later. Evolutionary Psychological Science, 2(3), 171176.

Becker, G. S. (1981). A Treatise on the Family. Harvard university press.

Bercholz, M., \& FitzGerald, J. (2016). Recent trends in female labour force participation in Ireland. Quarterly Economic Commentary, 49-81.

Bertrand, M., Cortés, P., Olivetti, C., \& Pan, J. (2016). Social norms, labor market opportunities, and the marriage gap for skilled women. National Bureau of Economic Research.

Bertrand, M., Cortes, P., Olivetti, C., \& Pan, J. (2020). Social Norms, Labor Market Opportunities, and the Marriage Gap Between Skilled and Unskilled Women. The Review of Economic Studies.

Billari, F. C., Goisis, A., Liefbroer, A. C., Settersten, R. A., Aassve, A., Hagestad, G., \& Spéder, Z. (2011). Social age deadlines for the childbearing of women and men. Human Reproduction, 26(3), 616-622.

Blau, P. M. (1977). A macrosociological theory of social structure. American Journal of Sociology, 83(1), 26-54.

Blau, P. M., Blum, T. C., \& Schwartz, J. E. (1982). Heterogeneity and intermarriage. American Sociological Review, 45-62.

Blossfeld, H.-P. (2009). Educational assortative marriage in comparative perspective. Annual Review of Sociology, 35, 513-530. 
Blossfeld, H.-P., \& Timm, A. (2017). Der Einfluß des Bildungssystems auf den Heiratsmarkt. Koelner Zeitschrift Für Soziologie Und Sozialpsychologie, 69, $645-681$.

Blum, T. C. (1985). Structural constraints on interpersonal relations: A test of Blau's macrosociological theory. American Journal of Sociology, 91(3), 511-521.

Breen, R., \& Andersen, S. H. (2012). Educational assortative mating and income inequality in Denmark. Demography, 49(3), 867-887.

Breen, R., \& Salazar, L. (2011). Educational assortative mating and earnings inequality in the United States. American Journal of Sociology, 117(3), 808-843.

Buss, D. M., Shackelford, T. K., Kirkpatrick, L. A., \& Larsen, R. J. (2001). A half century of mate preferences: The cultural evolution of values. Journal of Marriage and Family, 63(2), 491-503.

Central Statistics Office. (2015). Marriages and Civil Partnerships 2014. https://www.cso.ie/en/releasesandpublications/er/mcp/marriagesandcivilpartner ships2014/

$\begin{array}{lllll}\text { Central } & \text { Statistics } & \text { Office. } & \text { (2021). }\end{array}$ https://www.cso.ie/en/releasesandpublications/ep/pmar/marriages2020/marriages2020mainresults/

De Hauw, Y., Grow, A., \& Van Bavel, J. (2017). The reversed gender gap in education and assortative mating in Europe. European Journal of Population, 33(4), 445474.

Deming, W. E., \& Stephan, F. F. (1940). On a least squares adjustment of a sampled frequency table when the expected marginal totals are known. The Annals of Mathematical Statistics, 11(4), 427-444. 
Domański, H., \& Przybysz, D. (2007). Educational homogamy in 22 European countries. European Societies, 9(4), 495-526.

England, P., \& Farkas. (1986). Households, employment, and gender: A social, economic, and demographic view. Routledge.

Esteve, A., Schwartz, C. R., Van Bavel, J., Permanyer, I., Klesment, M., \& Garcia, J. (2016). The end of hypergamy: Global trends and implications. Population and Development Review, 42(4), 615.

Gihleb, R., \& Lang, K. (2016). Educational homogamy and assortative mating have not increased. National Bureau of Economic Research.

Goldstein, J. R., \& Kenney, C. T. (2001). Marriage delayed or marriage forgone? New cohort forecasts of first marriage for US women. American Sociological Review, $506-519$.

Halpin, B., \& Chan, T. W. (2003). Educational homogamy in Ireland and Britain: Trends and patterns. The British Journal of Sociology, 54(4), 473-495.

Hiekel, N., Liefbroer, A. C., \& Poortman, A.-R. (2014). Income pooling strategies among cohabiting and married couples: A comparative perspective. Demographic Research, 30, 1527-1560.

Kalmijn, M. (1991). Status homogamy in the United States. American Journal of Sociology, 97(2), 496-523.

Kalmijn, M. (2013). The educational gradient in marriage: A comparison of 25 European countries. Demography, 50(4), 1499-1520.

Katrňák, T., \& Manea, B. C. (2020). Change in prevalence or preference? Trends in educational homogamy in six European countries in a time of educational expansion. Social Science Research, 91, 102460. 
Kiernan, K. (2001). The rise of cohabitation and childbearing outside marriage in Western Europe. International Journal of Law, Policy and the Family, 15(1), 121.

Leridon, H. (2004). Can assisted reproduction technology compensate for the natural decline in fertility with age? A model assessment. Human Reproduction, 19(7), 1548-1553. https://doi.org/10.1093/humrep/deh304

Lewis, S. K., \& Oppenheimer, V. K. (2000). Educational assortative mating across marriage markets: Nonhispanic whites in the United States. Demography, 37(1), $29-40$.

Logan, J. A., Hoff, P. D., \& Newton, M. A. (2008). Two-sided estimation of mate preferences for similarities in age, education, and religion. Journal of the American Statistical Association, 103(482), 559-569.

Lomax, N., \& Norman, P. (2016). Estimating population attribute values in a table:"get me started in" iterative proportional fitting. The Professional Geographer, 68(3), $451-461$

Lundberg, S., Pollak, R. A., \& Stearns, J. (2016). Family Inequality: Diverging Patterns in Marriage, Cohabitation, and Childbearing. Journal of Economic Perspectives, 30(2), 79-102. https://doi.org/10.1257/jep.30.2.79

Mare, R. D. (1991). Five decades of educational assortative mating. American Sociological Review, 15-32.

McCall, L., \& Percheski, C. (2010). Income inequality: New trends and research directions. Annual Review of Sociology, 36, 329-347.

McGuinness, S., McGinnity, F., \& O’Connell, P. J. (2009). Changing returns to education during a boom? The case of Ireland. Labour, 23, 197-221. 
McLanahan, S. (2004). Diverging destinies: How children are faring under the second demographic transition. Demography, 41(4), 607-627.

Minnesota Population Center. (2020). Integrated Public Use Microdata Series, International: Version 7.3 (7.3) [Data set]. Minneapolis, MN: IPUMS. https://doi.org/10.18128/D020.V7.3

OECD. (1999). Education at a Glance 1998: OECD Indicators. OECD. https://doi.org/10.1787/eag-1998-en

OECD. (2020). Education at a Glance 2020: OECD Indicators. OECD. https://doi.org/10.1787/69096873-en

Oppenheimer, V. K. (1988). A theory of marriage timing. American Journal of Sociology, 94(3), 563-591.

Oppenheimer, V. K. (1994). Women's rising employment and the future of the family in industrial societies. Population and Development Review, 293-342.

Permanyer, I., Esteve, A., \& Garcia, J. (2019). Decomposing patterns of college marital sorting in 118 countries: Structural constraints versus assortative mating. Social Science Research, 83, 102313.

Schwartz, C. R. (2013). Trends and variation in assortative mating: Causes and consequences. Annual Review of Sociology, 39, 451-470.

Schwartz, C. R., \& Mare, R. D. (2005). Trends in educational assortative marriage from 1940 to 2003. Demography, 42(4), 621-646.

Schwartz, C. R., \& Mare, R. D. (2012). The proximate determinants of educational homogamy: The effects of first marriage, marital dissolution, remarriage, and educational upgrading. Demography, 49(2), 629-650. 
Smits, J. (2003). Social closure among the higher educated: Trends in educational homogamy in 55 countries. Social Science Research, 32(2), 251-277.

Smits, J., Ultee, W., \& Lammers, J. (1998). Educational homogamy in 65 countries: An explanation of differences in openness using country-level explanatory variables. American Sociological Review, 264-285.

Smits, J., Ultee, W., \& Lammers, J. (2000). More or less educational homogamy? A test of different versions of modernization theory using cross-temporal evidence for 60 countries. American Sociological Review, 65(5), 781-788.

Thévenon, O. (2013). Drivers of female labour force participation in the OECD.

Torr, B. M. (2011). The changing relationship between education and marriage in the United States, 1940-2000. Journal of Family History, 36(4), 483-503.

Vincent-Lancrin, S. (2008). The reversal of gender inequalities in higher education.

Whelan, C. T., \& Layte, R. (2002). Late industrialization and the increased merit selection hypothesis. Ireland as a test case. European Sociological Review, 18(1), $35-50$.

Zentner, M., \& Mitura, K. (2012). Stepping out of the caveman's shadow: Nations' gender gap predicts degree of sex differentiation in mate preferences. Psychological Science, 23(10), 1176-1185. 
Table 1. Decomposition of changes in marriage outcomes

\begin{tabular}{|c|c|c|c|c|c|c|}
\hline Outcome & $\begin{array}{l}\text { T1 } \\
1991\end{array}$ & $\begin{array}{l}\text { T2 } \\
1996\end{array}$ & 2002 & 2006 & 2011 & 2016 \\
\hline \multicolumn{7}{|l|}{ Homogamy } \\
\hline Level & $\begin{array}{l}0.5444^{* * *} \\
(0.0039)\end{array}$ & $\begin{array}{l}0.5655^{\text {****}} \\
(0.0041)\end{array}$ & $\begin{array}{c}0.5458^{* * *} \\
(0.0041)\end{array}$ & $\begin{array}{c}0.5586^{* * *} \\
(0.0037)\end{array}$ & $\begin{array}{c}0.5812^{* * *} \\
(0.0035)\end{array}$ & $\begin{array}{c}0.5953^{* * *} \\
(0.0039)\end{array}$ \\
\hline Difference T2-T1 & - & $\begin{array}{l}0.0211^{* * * *} \\
(0.0055)\end{array}$ & $\begin{array}{c}0.0014 \\
(0.0054)\end{array}$ & $\begin{array}{l}0.0143^{* *} \\
(0.0053)\end{array}$ & $\begin{array}{l}0.0369^{* * * *} \\
(0.0052)\end{array}$ & $\begin{array}{l}0.0510^{* * * *} \\
(0.0057)\end{array}$ \\
\hline \multicolumn{7}{|l|}{ Decomposition } \\
\hline Matching & - & $\begin{array}{c}0.0108 \\
(0.0055)\end{array}$ & $\begin{array}{l}-0.0111 \\
(0.0056)\end{array}$ & $\begin{array}{l}-0.0080 \\
(0.0055)\end{array}$ & $\begin{array}{l}-0.0040 \\
(0.0057)\end{array}$ & $\begin{array}{l}-0.0010 \\
(0.0062)\end{array}$ \\
\hline Educ. expansion & - & $\begin{array}{l}0.0092^{* * *} \\
(0.0014)\end{array}$ & $\begin{array}{l}0.0094^{* * *} \\
(0.0021)\end{array}$ & $\begin{array}{l}0.0193^{* * *} \\
(0.0026)\end{array}$ & $\begin{array}{l}0.0333^{\text {*** }} \\
(0.0032)\end{array}$ & $\begin{array}{l}0.0456^{* * * *} \\
(0.0035)\end{array}$ \\
\hline Marriage gradient & - & $\begin{array}{c}0.0011 \\
(0.0019)\end{array}$ & $\begin{array}{c}0.0030 \\
(0.0022)\end{array}$ & $\begin{array}{c}0.0029 \\
(0.0021)\end{array}$ & $\begin{array}{c}0.0075^{* *} \\
(0.0025)\end{array}$ & $\begin{array}{r}0.0064^{*} \\
(0.0025)\end{array}$ \\
\hline \multicolumn{7}{|l|}{ Marrying down } \\
\hline Level & $\begin{array}{l}0.2652^{* * * *} \\
(0.0035)\end{array}$ & $\begin{array}{l}0.2553^{* * *} \\
(0.0036)\end{array}$ & $\begin{array}{l}0.2906^{* * *} \\
(0.0037)\end{array}$ & $\begin{array}{l}0.2992^{* * *} \\
(0.0035)\end{array}$ & $\begin{array}{l}0.3102^{* * *} \\
(0.0033)\end{array}$ & $\begin{array}{l}0.2972^{* * *} \\
(0.0036)\end{array}$ \\
\hline Difference T2-T1 & - & $\begin{array}{l}-0.0100^{*} \\
(0.0049)\end{array}$ & $\begin{array}{l}0.0254^{* * * *} \\
(0.0050)\end{array}$ & $\begin{array}{l}0.0340^{\text {**** }} \\
(0.0050)\end{array}$ & $\begin{array}{l}0.0450^{\text {**** }} \\
(0.0048)\end{array}$ & $\begin{array}{l}0.0320^{* * * *} \\
(0.0051)\end{array}$ \\
\hline \multicolumn{7}{|l|}{ Decomposition } \\
\hline Matching & - & $\begin{array}{l}-0.0055 \\
(0.0030)\end{array}$ & $\begin{array}{c}0.0075^{*} \\
(0.0030)\end{array}$ & $\begin{array}{c}0.0067^{*} \\
(0.0030)\end{array}$ & $\begin{array}{c}0.0048 \\
(0.0031)\end{array}$ & $\begin{array}{c}0.0045 \\
(0.0034)\end{array}$ \\
\hline Educ. expansion & - & $\begin{array}{l}-0.0086^{*} \\
(0.0043)\end{array}$ & $\begin{array}{c}0.0108^{*} \\
(0.0047)\end{array}$ & $\begin{array}{l}0.0139^{* * *} \\
(0.0046)\end{array}$ & $\begin{array}{l}0.0299^{* * *} \\
(0.0050)\end{array}$ & $\begin{array}{l}0.0183^{* * *} \\
(0.0053)\end{array}$ \\
\hline Marriage gradient & - & $\begin{array}{c}0.0041 \\
(0.0059)\end{array}$ & $\begin{array}{c}0.0071 \\
(0.0062)\end{array}$ & $\begin{array}{c}0.0133^{*} \\
(0.0059)\end{array}$ & $\begin{array}{c}0.0103 \\
(0.0062)\end{array}$ & $\begin{array}{c}0.0091 \\
(0.0065)\end{array}$ \\
\hline \multicolumn{7}{|l|}{ Marrying up } \\
\hline Level & $\begin{array}{l}0.1904^{* * *} \\
(0.0031)\end{array}$ & $\begin{array}{l}0.1793^{* * *} \\
(0.0031)\end{array}$ & $\begin{array}{l}0.1636^{* * *} \\
(0.0030)\end{array}$ & $\begin{array}{l}0.1421^{* * *} \\
(0.0026)\end{array}$ & $\begin{array}{l}0.1085^{* * *} \\
(0.0022)\end{array}$ & $\begin{array}{c}0.1074^{* * * *} \\
(0.0024)\end{array}$ \\
\hline Difference T2-T1 & - & $\begin{array}{l}-0.0111^{*} \\
(0.0048)\end{array}$ & $\begin{array}{l}-0.0268^{* * *} \\
(0.0044)\end{array}$ & $\begin{array}{l}-0.0483^{* * *} \\
(0.0041)\end{array}$ & $\begin{array}{l}-0.0818^{* * *} \\
(0.0038)\end{array}$ & $\begin{array}{l}-0.0829^{* * *} \\
(0.0041)\end{array}$ \\
\hline \multicolumn{7}{|l|}{ Decomposition } \\
\hline Matching & - & $\begin{array}{l}-0.0053 \\
(0.0030)\end{array}$ & $\begin{array}{c}0.0036 \\
(0.0031)\end{array}$ & $\begin{array}{c}0.0012 \\
(0.0029)\end{array}$ & $\begin{array}{l}-0.0009 \\
(0.0031)\end{array}$ & $\begin{array}{l}-0.0036 \\
(0.0033)\end{array}$ \\
\hline Educ. expansion & - & $\begin{array}{l}-0.0006 \\
(0.0033)\end{array}$ & $\begin{array}{l}-0.0202^{* * *} \\
(0.0034)\end{array}$ & $\begin{array}{l}-0.0333^{* * *} \\
(0.0033)\end{array}$ & $\begin{array}{l}-0.0632^{* * *} \\
(0.0034)\end{array}$ & $\begin{array}{l}-0.0639^{* * *} \\
(0.0037)\end{array}$ \\
\hline Marriage gradient & - & $\begin{array}{l}-0.0052 \\
(0.0047)\end{array}$ & $\begin{array}{l}-0.0101^{*} \\
(0.0046)\end{array}$ & $\begin{array}{l}-0.0162^{* * *} \\
(0.0043)\end{array}$ & $\begin{array}{l}-0.0177^{\text {*** }} \\
(0.0042)\end{array}$ & $\begin{array}{l}-0.0154^{* * *} \\
(0.0045)\end{array}$ \\
\hline$N$ & 15767 & 14961 & 15068 & 17598 & 19650 & 16231 \\
\hline
\end{tabular}

Notes: Standard errors in parentheses. Standard errors for difference and decomposition terms estimated via bootstrapping. Outcomes: Homogamy (equal education level for wife and husband), marrying down (wife higher educated), marrying up (husband higher educated). Significance: $* \mathrm{p}<.05, * * \mathrm{p}<.01, * * * \mathrm{p}<.001$. 


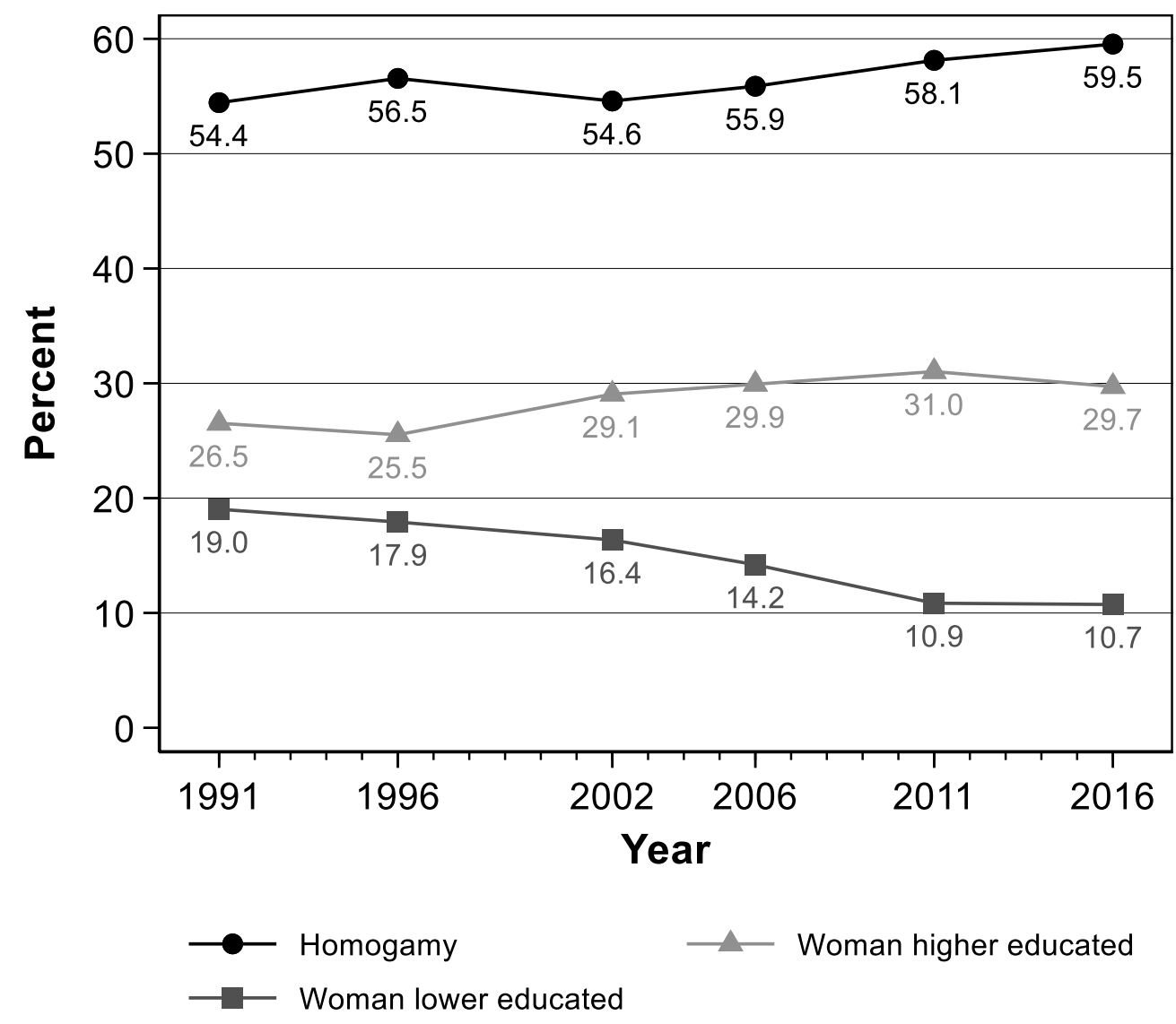

Figure 1. Marriage outcomes of 25-34-year-old women 
(a) Women

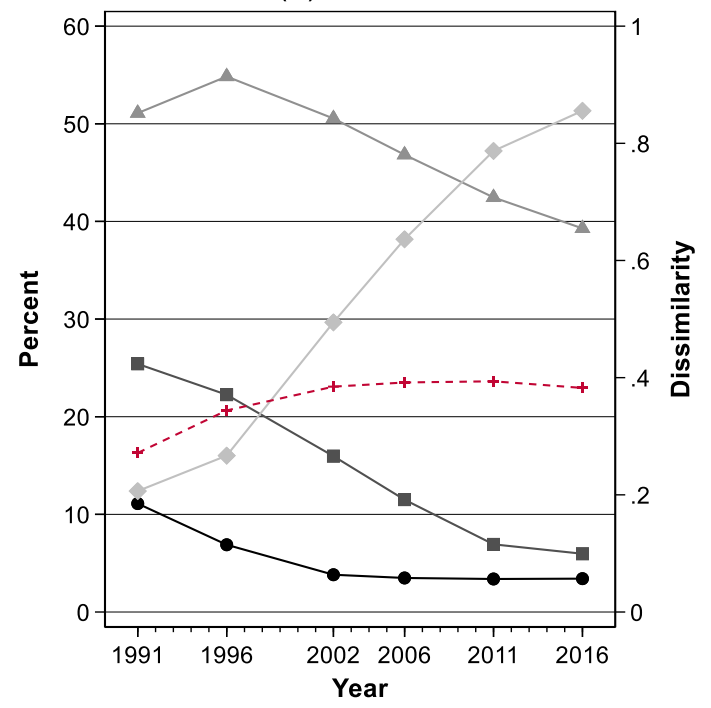

(b) Men

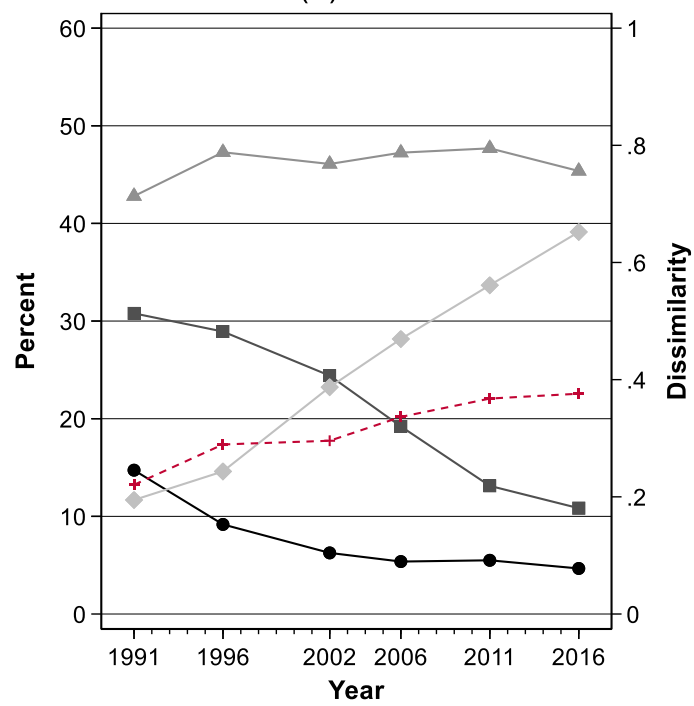

Primary or less

- Lower secondary

$\longrightarrow$ Higher secondary

--+-- Dissimilarity

Figure 2. Educational attainment and dissimilarity index, women (age $25-34)$ and men (age 27-36) 

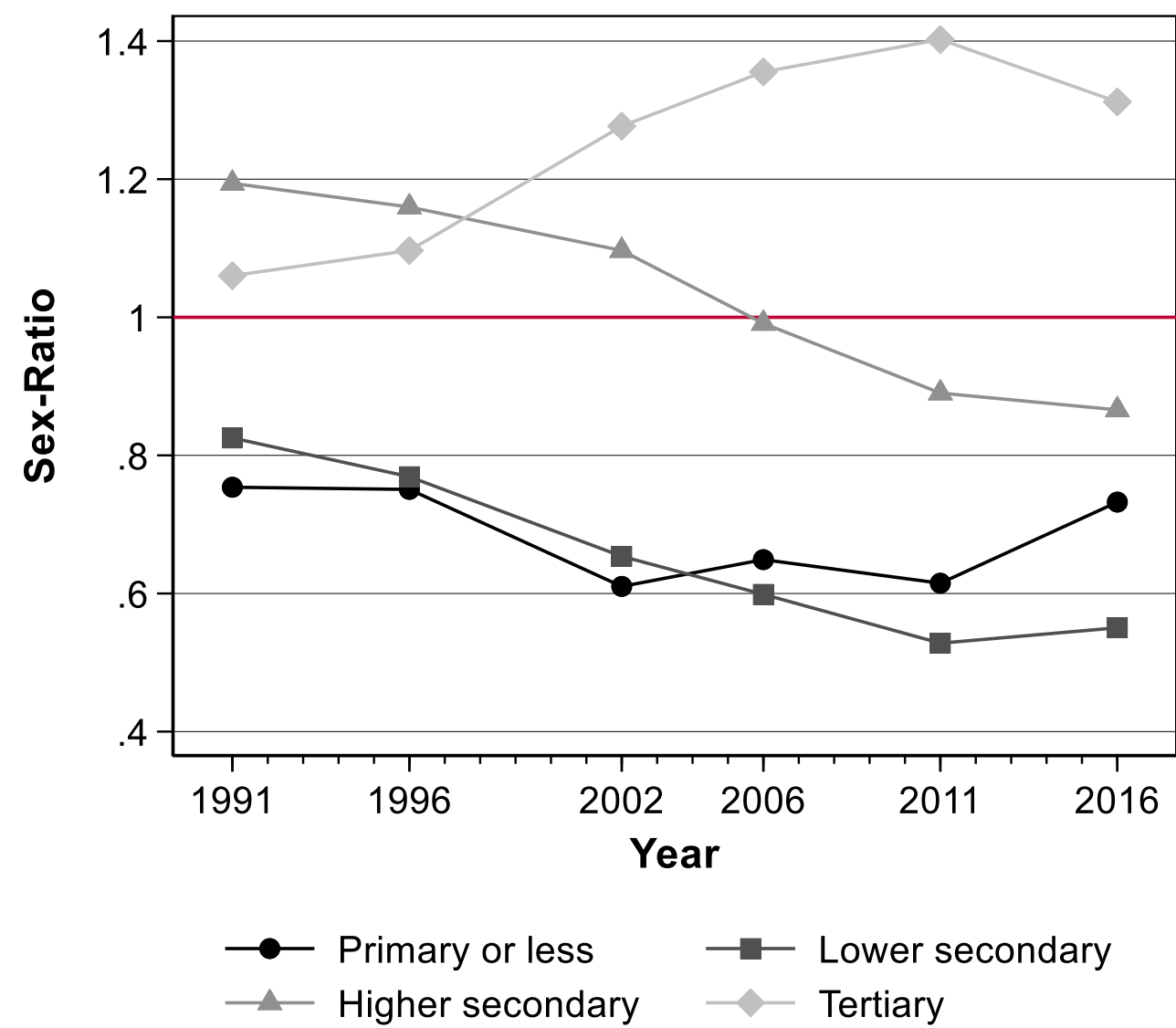

Figure 3. Sex-ratios (women/men) in educational attainment, women (age 25 - 34) and men (age $27-36)$ 
(a) Women

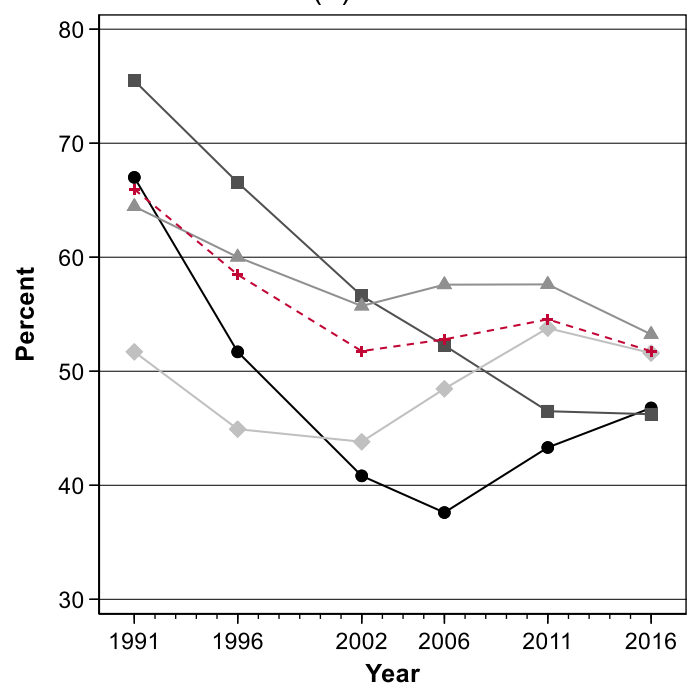

(b) Men

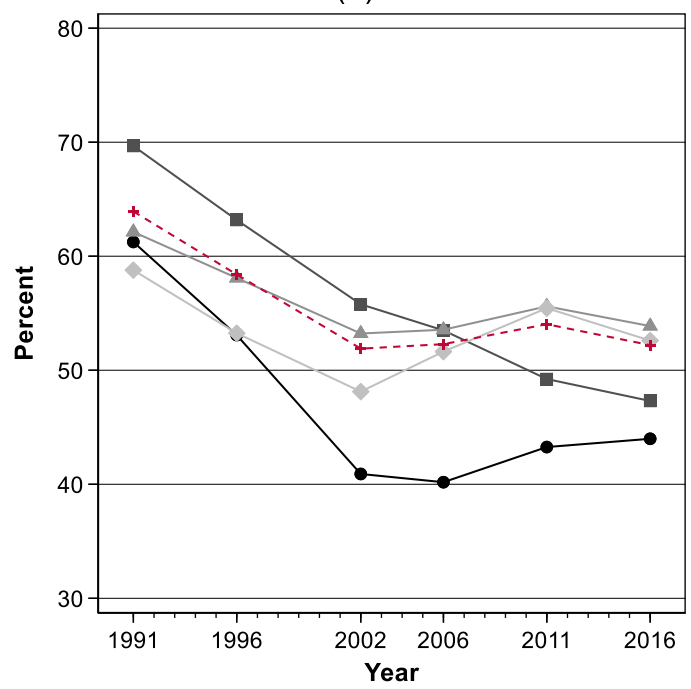

$\longrightarrow$ Primary or less $\quad \longrightarrow$ Lower secondary

Figure 4. Share of married women (age 25 - 34) and men (age 27 - 36) by education 
(a) Homogamy

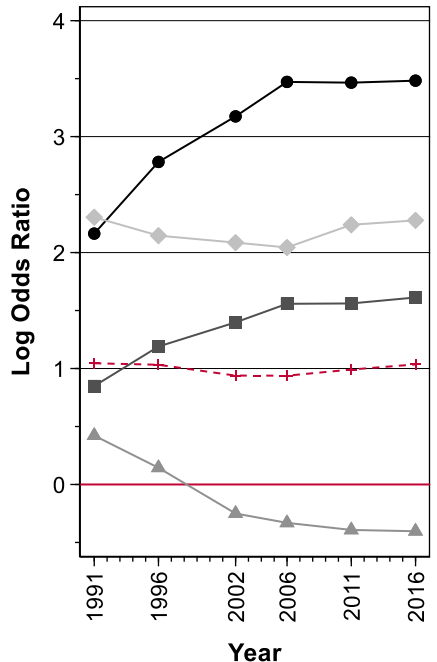

Year (b) Marrying down

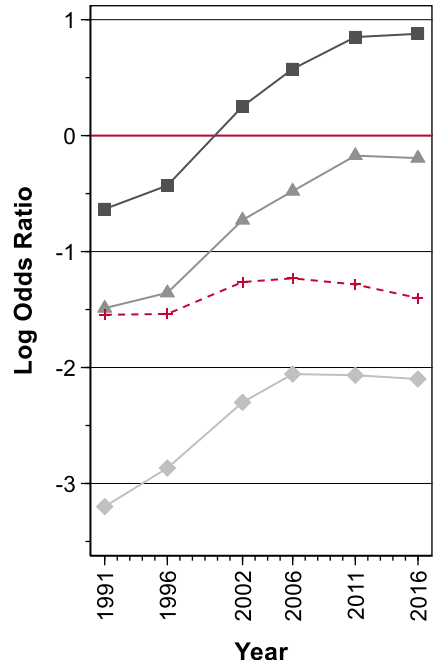

Year (c) Marrying up

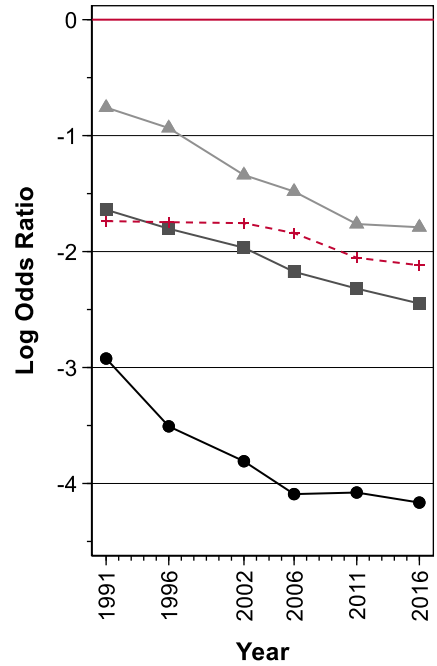

Tertiary $\quad--+\cdots$ Aggregate (all)

Figure 5. Trends in educational matching

Note: Outcomes: Homogamy (equal education level for wife and husband), marrying down (wife higher educated), marrying up (husband higher educated). 


\section{Online Appendix}

\section{A Figures}

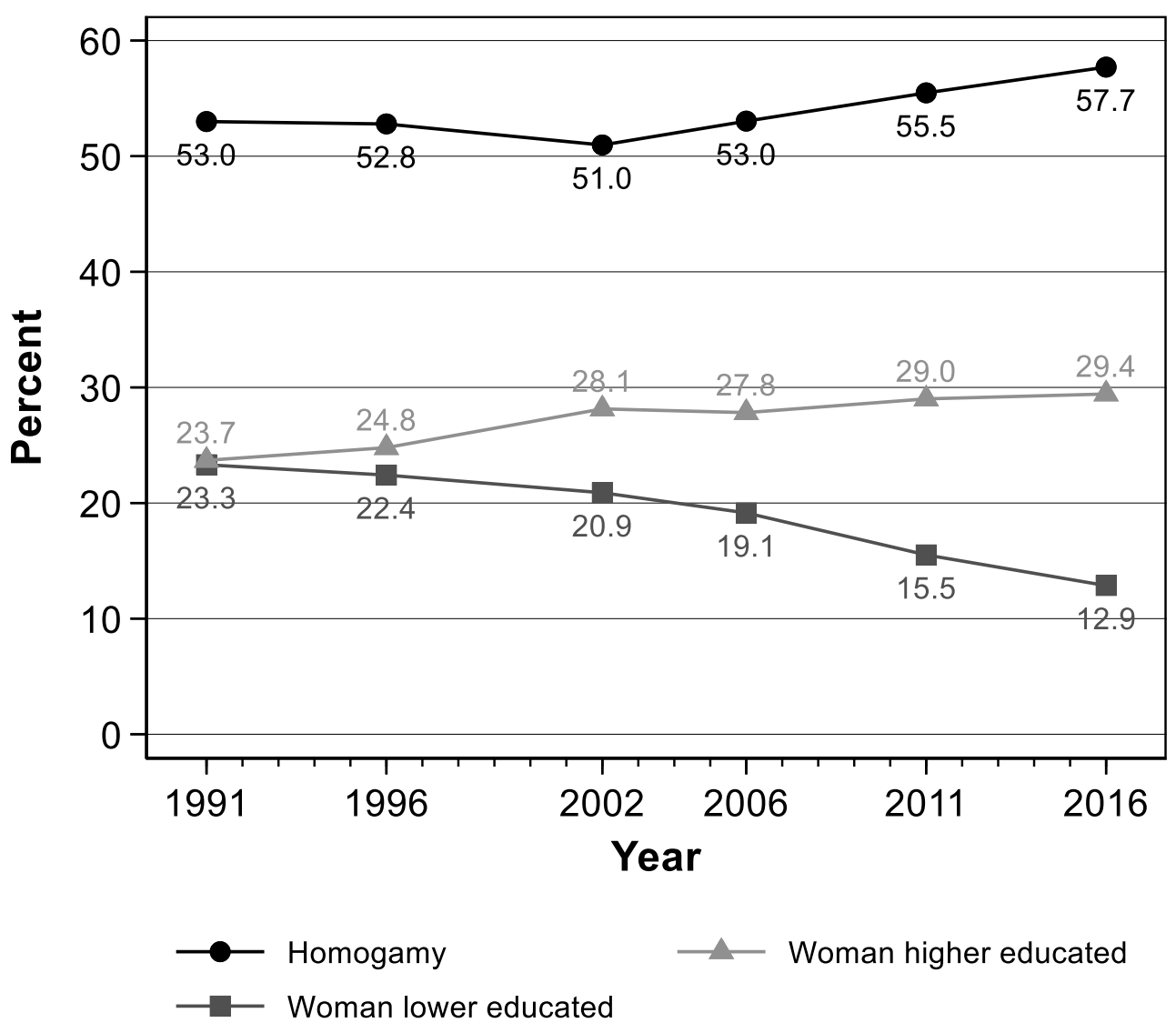

Figure A1. Marriage outcomes of 35-44-year-old women 
(a) Women

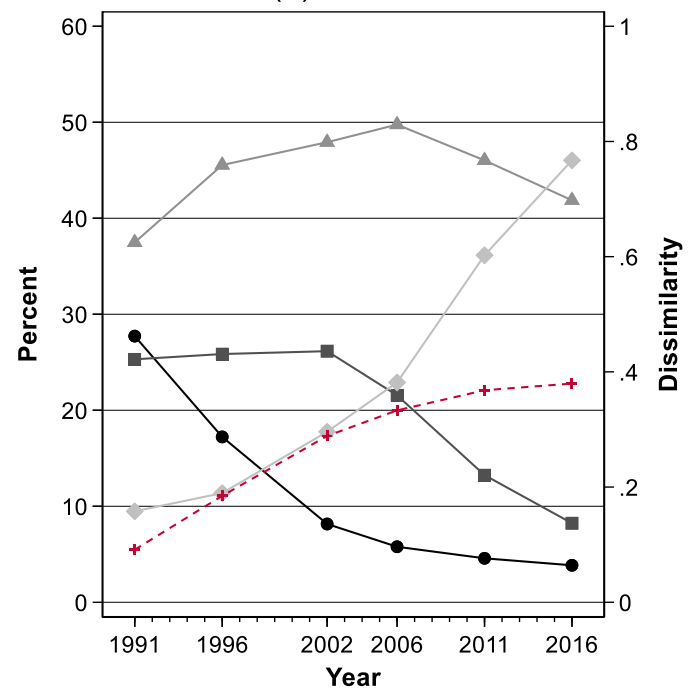

(b) Men

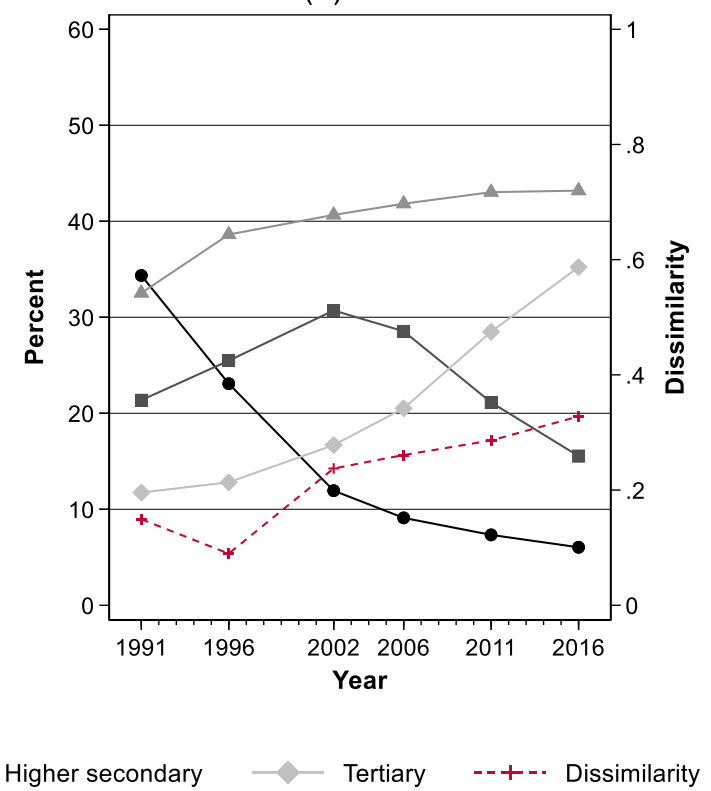

Figure A2. Educational attainment and dissimilarity index, women (age 35 - 44) and men (age 37-46) 


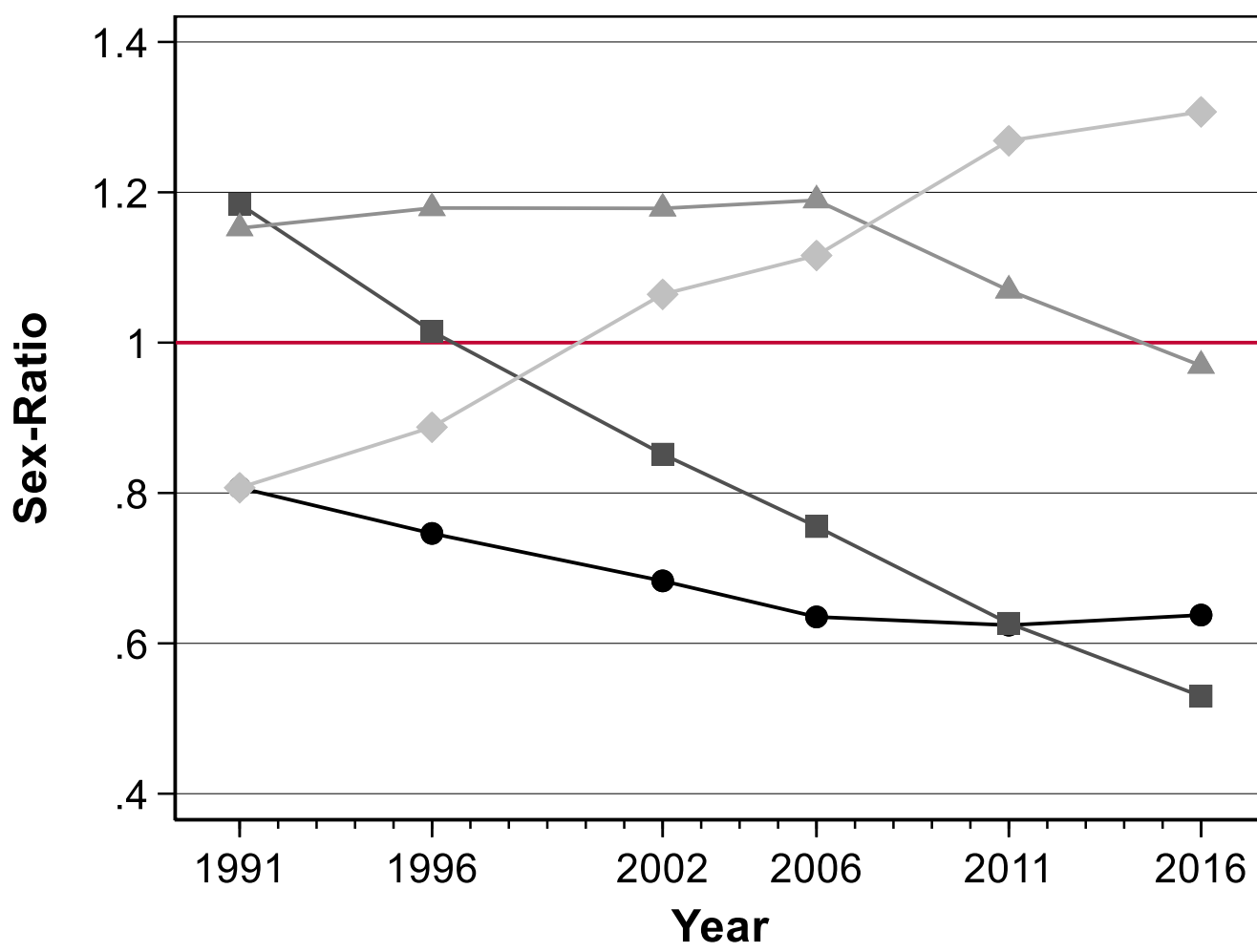

- Primary or less

- Lower secondary

- Higher secondary

\section{Tertiary}

Figure A3. Sex-ratios (women/men) in educational attainment, women (age 35 - 44) and men (age $37-46$ ) 
(a) Women

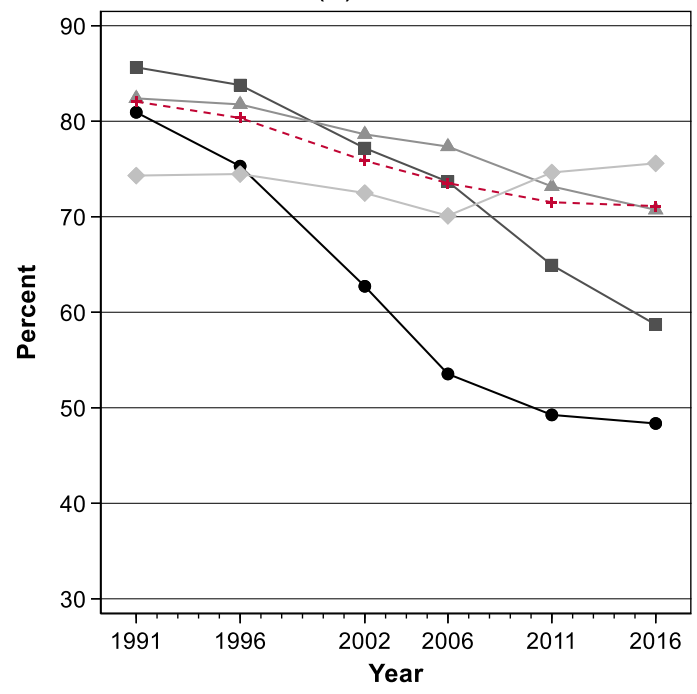

(b) Men

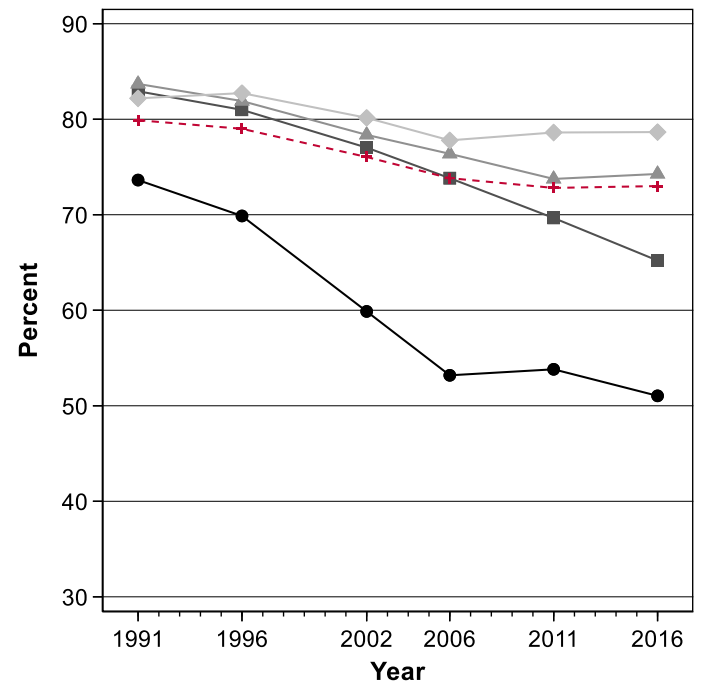

— Primary or less

—— Lower secondary

Higher secondary

Tertiary

--+-. Total

Figure A4. Share of married women (age 35 - 44) and men (age 37 - 46) by education 


\section{B Tables}

Table B1. Case numbers throughout the sample selection

\begin{tabular}{lllllll}
\hline & 1991 & 1996 & 2002 & 2006 & 2011 & 2016 \\
\hline All cases & 258,909 & 278,310 & 306,120 & 333,369 & 354,024 & 371,215 \\
- men & 132,019 & 141,649 & 154,959 & 167,530 & 180,205 & 189,525 \\
- women aged <25 & 25,253 & 26,667 & 30,653 & 35,185 & 37,887 & 33,583 \\
$\quad$ and > 34 & & & & & & \\
$\begin{array}{l}\text { - partner in another } \\
\quad \text { household }\end{array}$ & 24,675 & 26,232 & 30,097 & 34,546 & 37,422 & 33,093 \\
- missing values & 23,904 & 25,584 & 29,108 & 33,330 & 36,020 & 31,360 \\
- unpartnered & 15,767 & 14,961 & 15,068 & 17,598 & 19,650 & 16,231 \\
\hline
\end{tabular}


Table B2. Factual and counterfactual marriage outcomes, two-fold decomposition

$$
\text { Preferences }\left(\boldsymbol{O} \boldsymbol{R}_{t}\right)
$$

$\begin{array}{lcc}\text { Opportunities }\left(\boldsymbol{E}_{t}^{W}, \boldsymbol{E}_{t}^{H}\right) & \mathrm{T}=1 & \mathrm{~T}=2 \\ \mathrm{ny}=1 & Y_{11} & \dot{Y}_{12} \\ \mathrm{~T}=2 & \dot{Y}_{21} & Y_{22}\end{array}$


Table B3. Factual and counterfactual marriage outcomes, three-fold decomposition

\begin{tabular}{llll}
\hline $\begin{array}{l}\text { Opportunities }\left(E\left(\boldsymbol{G}_{t}^{F}, \boldsymbol{E}_{t}^{F}\right), E\left(\boldsymbol{G}_{t}^{M}, \boldsymbol{E}_{t}^{M}\right)\right) \\
\text { Education } \\
\text { distributions }\end{array}$ & Marriage gradients & & \\
$\left(\boldsymbol{E}_{t}^{F}, \boldsymbol{E}_{t}^{M}\right)$ & $\left(\boldsymbol{G}_{t}^{F}, \boldsymbol{G}_{t}^{M}\right)$ & & \\
& & $\mathrm{T}=1$ & $\mathrm{~T}=2$ \\
$\mathrm{n}=1$ & $\mathrm{~T}=1$ & $Y_{111}$ & $\dot{Y}_{112}$ \\
$\mathrm{~T}=1$ & $\mathrm{~T}=2$ & $\dot{Y}_{121}$ & $\dot{Y}_{122}$ \\
$\mathrm{~T}=2$ & $\dot{Y}_{211}$ & $\dot{Y}_{212}$ \\
$\mathrm{~T}=2$ & $\dot{Y}_{221}$ & $Y_{222}$ \\
\hline
\end{tabular}


Table B4. Decomposition of changes in marriage outcomes, women age (35 - 44)

\begin{tabular}{|c|c|c|c|c|c|c|}
\hline Outcome & $\begin{array}{l}\text { T1 } \\
1991\end{array}$ & $\begin{array}{l}\text { T2 } \\
1996 \\
\end{array}$ & 2002 & 2006 & 2011 & 2016 \\
\hline \multicolumn{7}{|l|}{ Homogamy } \\
\hline Level & $\begin{array}{l}0.5299^{* * *} \\
(0.0037)\end{array}$ & $\begin{array}{c}0.5279^{* * *} \\
(0.0036)\end{array}$ & $\begin{array}{c}0.5097^{* * *} \\
(0.0035)\end{array}$ & $\begin{array}{l}0.5303^{\text {*** }} \\
(0.0034)\end{array}$ & $\begin{array}{l}0.5548^{* * * *} \\
(0.0033)\end{array}$ & $\begin{array}{c}0.5770^{* * * *} \\
(0.0031)\end{array}$ \\
\hline Difference T2-T1 & - & $\begin{array}{l}-0.0020 \\
(0.0053)\end{array}$ & $\begin{array}{l}-0.0203^{\text {**** }} \\
(0.0049)\end{array}$ & $\begin{array}{c}0.0004 \\
(0.0049)\end{array}$ & $\begin{array}{l}0.0248^{* * * *} \\
(0.0049)\end{array}$ & $\begin{array}{l}0.0471^{* * * *} \\
(0.0053)\end{array}$ \\
\hline \multicolumn{7}{|l|}{ Decomposition } \\
\hline Matching & - & $\begin{array}{c}0.0073 \\
(0.0052)\end{array}$ & $\begin{array}{l}-0.0118^{*} \\
(0.0050)\end{array}$ & $\begin{array}{c}0.0050 \\
(0.0051)\end{array}$ & $\begin{array}{c}0.0071 \\
(0.0052)\end{array}$ & $\begin{array}{c}0.0063 \\
(0.0060)\end{array}$ \\
\hline Educ. expansion & - & $\begin{array}{l}-0.0077^{* * *} \\
(0.0013)\end{array}$ & $\begin{array}{l}-0.0063^{* *} \\
(0.0019)\end{array}$ & $\begin{array}{l}-0.0012 \\
(0.0024)\end{array}$ & $\begin{array}{l}0.0204^{* * * *} \\
(0.0030)\end{array}$ & $\begin{array}{c}0.0389^{* * * *} \\
(0.0036)\end{array}$ \\
\hline Marriage gradient & - & $\begin{array}{l}-0.0016 \\
(0.0016)\end{array}$ & $\begin{array}{l}-0.0022 \\
(0.0015)\end{array}$ & $\begin{array}{l}-0.0034^{*} \\
(0.0016)\end{array}$ & $\begin{array}{l}-0.0026 \\
(0.0019)\end{array}$ & $\begin{array}{c}0.0019 \\
(0.0020)\end{array}$ \\
\hline \multicolumn{7}{|l|}{ Marrying down } \\
\hline Level & $\begin{array}{c}0.2369^{* * *} \\
(0.0032)\end{array}$ & $\begin{array}{l}0.2479^{* * *} \\
(0.0031)\end{array}$ & $\begin{array}{l}0.2814^{* * *} \\
(0.0032)\end{array}$ & $\begin{array}{l}0.2782^{* * *} \\
(0.0031)\end{array}$ & $\begin{array}{l}0.2901^{* * *} \\
(0.0030)\end{array}$ & $\begin{array}{l}0.2943^{\text {*** }} \\
(0.0030)\end{array}$ \\
\hline Difference T2-T1 & - & $\begin{array}{r}0.0110^{*} \\
(0.0045)\end{array}$ & $\begin{array}{l}0.0445^{* * * *} \\
(0.0046)\end{array}$ & $\begin{array}{l}0.0413^{* * * *} \\
(0.0045)\end{array}$ & $\begin{array}{l}0.0532^{\text {**** }} \\
(0.0044)\end{array}$ & $\begin{array}{l}0.0574^{\text {**** }} \\
(0.0044)\end{array}$ \\
\hline \multicolumn{7}{|l|}{ Decomposition } \\
\hline Matching & - & $\begin{array}{l}-0.0027 \\
(0.0029)\end{array}$ & $\begin{array}{c}0.0095^{\text {*** }} \\
(0.0028)\end{array}$ & $\begin{array}{c}0.0030 \\
(0.0028)\end{array}$ & $\begin{array}{c}0.0021 \\
(0.0029)\end{array}$ & $\begin{array}{c}0.0053 \\
(0.0034)\end{array}$ \\
\hline Educ. expansion & - & $\begin{array}{l}0.0114^{* *} \\
(0.0041)\end{array}$ & $\begin{array}{l}0.0307^{\text {*** }} \\
(0.0046)\end{array}$ & $\begin{array}{l}0.0325^{* * *} \\
(0.0052)\end{array}$ & $\begin{array}{l}0.0327^{* * *} \\
(0.0051)\end{array}$ & $\begin{array}{l}0.0384^{* * *} \\
(0.0059)\end{array}$ \\
\hline Marriage gradient & - & $\begin{array}{c}0.0023 \\
(0.0052)\end{array}$ & $\begin{array}{c}0.0043 \\
(0.0058)\end{array}$ & $\begin{array}{c}0.0058 \\
(0.0060)\end{array}$ & $\begin{array}{l}0.0184^{* *} \\
(0.0058)\end{array}$ & $\begin{array}{r}0.0137^{*} \\
(0.0061)\end{array}$ \\
\hline \multicolumn{7}{|l|}{ Marrying up } \\
\hline Level & $\begin{array}{l}0.2331^{* * *} \\
(0.0032)\end{array}$ & $\begin{array}{l}0.2242^{\text {*** }} \\
(0.0030)\end{array}$ & $\begin{array}{l}0.2089^{* * *} \\
(0.0029)\end{array}$ & $\begin{array}{c}0.1915^{* * *} \\
(0.0027)\end{array}$ & $\begin{array}{c}0.1552^{* * *} \\
(0.0024)\end{array}$ & $\begin{array}{c}0.1286^{\text {*** }} \\
(0.0021)\end{array}$ \\
\hline Difference T2-T1 & - & $\begin{array}{l}-0.0089^{*} \\
(0.0043)\end{array}$ & $\begin{array}{l}-0.0242^{* * *} \\
(0.0042)\end{array}$ & $\begin{array}{l}-0.0417^{\text {**** }} \\
(0.0041)\end{array}$ & $\begin{array}{l}-0.0780^{\text {**** }} \\
(0.0039)\end{array}$ & $\begin{array}{l}-0.1045^{* * *} \\
(0.0038)\end{array}$ \\
\hline \multicolumn{7}{|l|}{ Decomposition } \\
\hline Matching & - & $\begin{array}{l}-0.0046 \\
(0.0028)\end{array}$ & $\begin{array}{c}0.0023 \\
(0.0028)\end{array}$ & $\begin{array}{l}-0.0080^{* *} \\
(0.0028)\end{array}$ & $\begin{array}{l}-0.0092^{* *} \\
(0.0029)\end{array}$ & $\begin{array}{l}-0.0116^{* * *} \\
(0.0032)\end{array}$ \\
\hline Educ. expansion & - & $\begin{array}{l}-0.0037 \\
(0.0037)\end{array}$ & $\begin{array}{l}-0.0244^{\text {*** }} \\
(0.0040)\end{array}$ & $\begin{array}{l}-0.0313^{\text {*** }} \\
(0.0043)\end{array}$ & $\begin{array}{l}-0.0530^{* * *} \\
(0.0039)\end{array}$ & $\begin{array}{l}-0.0773^{\text {*** }} \\
(0.0044)\end{array}$ \\
\hline Marriage gradient & - & $\begin{array}{l}-0.0007 \\
(0.0048)\end{array}$ & $\begin{array}{l}-0.0021 \\
(0.0051)\end{array}$ & $\begin{array}{l}-0.0024 \\
(0.0051)\end{array}$ & $\begin{array}{l}-0.0158^{* * *} \\
(0.0046)\end{array}$ & $\begin{array}{l}-0.0156^{* * *} \\
(0.0047)\end{array}$ \\
\hline$N$ & 17930 & 19261 & 20215 & 21178 & 23055 & 24745 \\
\hline
\end{tabular}

Notes: Standard errors in parentheses. Standard errors for difference and decomposition terms estimated via bootstrapping. Outcomes: Homogamy (equal education level for wife and husband), marrying down (wife higher educated), marrying up (husband higher educated). Significance: $* \mathrm{p}<.05, * * \mathrm{p}<.01, * * * \mathrm{p}<.001$. 
Table B5. Decomposition of changes in marriage outcomes, excluding international migrants

\begin{tabular}{|c|c|c|c|c|c|c|}
\hline Outcome & $\begin{array}{l}\text { T1 } \\
1991 \\
\end{array}$ & $\begin{array}{c}\text { T2 } \\
1996 \\
\end{array}$ & 2002 & 2006 & 2011 & 2016 \\
\hline Homogamy & $0.5438^{* * *}$ & $0.5650^{\text {**** }}$ & $0.5374^{* * *}$ & $0.5479^{* * *}$ & $0.5641^{* * *}$ & $0.5793^{* * *}$ \\
\hline Level & $(0.0041)$ & $(0.0043)$ & $(0.0044)$ & $(0.0040)$ & $(0.0039)$ & $(0.0043)$ \\
\hline Difference T2-T1 & - & $\begin{array}{l}0.0212^{* * *} \\
(0.0057)\end{array}$ & $\begin{array}{l}-0.0064 \\
(0.0057)\end{array}$ & $\begin{array}{c}0.0042 \\
(0.0059)\end{array}$ & $\begin{array}{l}0.0203^{* * *} \\
(0.0058)\end{array}$ & $\begin{array}{c}0.0355^{* * *} \\
(0.0060)\end{array}$ \\
\hline \multicolumn{7}{|l|}{ Decomposition } \\
\hline Matching & - & $\begin{array}{c}0.0105 \\
(0.0056)\end{array}$ & $\begin{array}{l}-0.0153^{* *} \\
(0.0058)\end{array}$ & $\begin{array}{l}-0.0102 \\
(0.0059)\end{array}$ & $\begin{array}{l}-0.0102 \\
(0.0060)\end{array}$ & $\begin{array}{l}-0.0070 \\
(0.0064)\end{array}$ \\
\hline Educ. expansion & - & $\begin{array}{l}0.0091^{* * * * *} \\
(0.0015)\end{array}$ & $\begin{array}{l}0.0063^{* * *} \\
(0.0022)\end{array}$ & $\begin{array}{l}0.0115^{\text {**** }} \\
(0.0027)\end{array}$ & $\begin{array}{l}0.0260^{* * * *} \\
(0.0034)\end{array}$ & $\begin{array}{l}0.0373^{* * *} \\
(0.0039)\end{array}$ \\
\hline Marriage gradient & - & $\begin{array}{c}0.0016 \\
(0.0020)\end{array}$ & $\begin{array}{c}0.0026 \\
(0.0022)\end{array}$ & $\begin{array}{c}0.0028 \\
(0.0024)\end{array}$ & $\begin{array}{c}0.0046 \\
(0.0027)\end{array}$ & $\begin{array}{r}0.0052^{*} \\
(0.0024)\end{array}$ \\
\hline \multicolumn{7}{|l|}{ Marrying down } \\
\hline Level & $\begin{array}{l}0.2683^{* * * *} \\
(0.0036)\end{array}$ & $\begin{array}{l}0.2585^{* * * *} \\
(0.0038)\end{array}$ & $\begin{array}{l}0.2993^{* * * *} \\
(0.0040)\end{array}$ & $\begin{array}{l}0.3099^{* * *} \\
(0.0038)^{* * * *}\end{array}$ & $\begin{array}{l}0.3243^{\text {**** }} \\
(0.0037)^{\text {* } * * *}\end{array}$ & $\begin{array}{l}0.3102^{* * * *} \\
(0.0040)\end{array}$ \\
\hline Difference T2-T1 & - & $\begin{array}{l}-0.0097^{*} \\
(0.0048)\end{array}$ & $\begin{array}{l}0.0310^{* * *} \\
(0.0055)\end{array}$ & $\begin{array}{l}0.0417^{\text {*** }} \\
(0.0051)\end{array}$ & $\begin{array}{l}0.0561^{* * *} \\
(0.0053)\end{array}$ & $\begin{array}{l}0.0419^{* * * *} \\
(0.0052)\end{array}$ \\
\hline \multicolumn{7}{|l|}{ Decomposition } \\
\hline Matching & - & $\begin{array}{l}-0.0056 \\
(0.0031)\end{array}$ & $\begin{array}{c}0.0090^{* *} \\
(0.0033)\end{array}$ & $\begin{array}{r}0.0077^{*} \\
(0.0032)\end{array}$ & $\begin{array}{r}0.0078^{*} \\
(0.0033)\end{array}$ & $\begin{array}{c}0.0071^{*} \\
(0.0034)\end{array}$ \\
\hline Educ. expansion & - & $\begin{array}{l}-0.0078 \\
(0.0045)\end{array}$ & $\begin{array}{l}0.0128^{* * *} \\
(0.0045)\end{array}$ & $\begin{array}{l}0.0203^{* * * *} \\
(0.0047)\end{array}$ & $\begin{array}{l}0.0328^{* * *} \\
(0.0054)\end{array}$ & $\begin{array}{l}0.0242^{* * *} \\
(0.0055)\end{array}$ \\
\hline Marriage gradient & - & $\begin{array}{c}0.0037 \\
(0.0059)\end{array}$ & $\begin{array}{c}0.0092 \\
(0.0065)\end{array}$ & $\begin{array}{r}0.0137^{*} \\
(0.0060)\end{array}$ & $\begin{array}{r}0.0154^{*} \\
(0.0066)\end{array}$ & $\begin{array}{c}0.0106 \\
(0.0064)\end{array}$ \\
\hline \multicolumn{7}{|l|}{ Marrying up } \\
\hline Level & $\begin{array}{l}0.1880^{* * *} \\
(0.0032)\end{array}$ & $\begin{array}{l}0.1765^{* * *} \\
(0.0033)\end{array}$ & $\begin{array}{l}0.1633^{* * *} \\
(0.0032)\end{array}$ & $\begin{array}{l}0.1421^{* * *} \\
(0.0028)\end{array}$ & $\begin{array}{c}0.1116^{* * *} \\
(0.0025)\end{array}$ & $\begin{array}{l}0.1106^{* * *} \\
(0.0027)\end{array}$ \\
\hline Difference T2-T1 & - & $\begin{array}{l}-0.0115^{*} \\
(0.0047)\end{array}$ & $\begin{array}{l}-0.0246^{* * * *} \\
(0.0047)\end{array}$ & $\begin{array}{l}-0.0459^{* * * *} \\
(0.0042)\end{array}$ & $\begin{array}{l}-0.0764^{* * *} \\
(0.0041)\end{array}$ & $\begin{array}{l}-0.0774^{* * *} \\
(0.0043)\end{array}$ \\
\hline \multicolumn{7}{|l|}{ Decomposition } \\
\hline Matching & - & $\begin{array}{l}-0.0049 \\
(0.0030)\end{array}$ & $\begin{array}{r}0.0063^{*} \\
(0.0031)\end{array}$ & $\begin{array}{c}0.0025 \\
(0.0032)\end{array}$ & $\begin{array}{c}0.0024 \\
(0.0032)\end{array}$ & $\begin{array}{l}-0.0001 \\
(0.0034)\end{array}$ \\
\hline Educ. expansion & - & $\begin{array}{l}-0.0013 \\
(0.0033)\end{array}$ & $\begin{array}{l}-0.0191^{* * *} \\
(0.0033)\end{array}$ & $\begin{array}{l}-0.0318^{\text {**** }} \\
(0.0032)\end{array}$ & $\begin{array}{l}-0.0588^{* * *} \\
(0.0035)\end{array}$ & $\begin{array}{l}-0.0615^{\text {**** }} \\
(0.0038)\end{array}$ \\
\hline Marriage gradient & - & $\begin{array}{l}-0.0053 \\
(0.0046)\end{array}$ & $\begin{array}{l}-0.0118^{*} \\
(0.0047)\end{array}$ & $\begin{array}{l}-0.0166^{* * *} \\
(0.0041)\end{array}$ & $\begin{array}{l}-0.0200^{* * * *} \\
(0.0044)\end{array}$ & $\begin{array}{l}-0.0158^{* * *} \\
(0.0046)\end{array}$ \\
\hline$N$ & 14911 & 13371 & 12967 & 15106 & 16370 & 13279 \\
\hline
\end{tabular}

Notes: Standard errors in parentheses. Standard errors for difference and decomposition terms estimated via bootstrapping. Outcomes: Homogamy (equal education level for wife and husband), marrying down (wife higher educated), marrying up (husband higher educated). Significance: $* \mathrm{p}<.05, * * \mathrm{p}<.01, * * * \mathrm{p}<.001$. 
Table B6. Data table year 1991

\begin{tabular}{l|lllll}
\hline Women's education & Men's education & & & \\
\hline & $\begin{array}{l}\text { Primary or } \\
\text { less }\end{array}$ & $\begin{array}{l}\text { Lower } \\
\text { Secondary }\end{array}$ & $\begin{array}{l}\text { Higher } \\
\text { Secondary }\end{array}$ & Tertiary & $\begin{array}{l}\text { All women } \\
\text { (married + } \\
\text { unmarried) }\end{array}$ \\
\hline $\begin{array}{l}\text { Primary or less } \\
\text { Lower Secondary }\end{array}$ & 987 & 472 & 308 & 12 & 2655 \\
$\begin{array}{l}\text { Higher Secondary } \\
\text { Tertiary }\end{array}$ & 580 & 2510 & 1292 & 100 & 6074 \\
$\begin{array}{l}\text { All men (married } \\
+ \text { unmarried) }\end{array}$ & 37 & 2146 & 4328 & 818 & 12214 \\
\hline
\end{tabular}


Table B7. Data table year 1996

\begin{tabular}{l|lllll}
\hline Women's education & Men's education & Tertiary & $\begin{array}{l}\text { All women } \\
\text { (married + } \\
\text { unmarried) }\end{array}$ \\
\hline & $\begin{array}{l}\text { Primary or } \\
\text { less }\end{array}$ & $\begin{array}{l}\text { Lower } \\
\text { Secondary }\end{array}$ & $\begin{array}{l}\text { Higher } \\
\text { Secondary }\end{array}$ & & 1762 \\
\hline Primary or less & 506 & 250 & 146 & 9 & 5693 \\
Lower Secondary & 399 & 2095 & 1213 & 82 & 14031 \\
$\begin{array}{l}\text { Higher Secondary } \\
\text { Tertiary }\end{array}$ & 379 & 2107 & 4952 & 982 & 8196 \\
$\begin{array}{l}\text { All men (married } \\
+ \text { unmarried) }\end{array}$ & 21 & 167 & 746 & 907 & 0 \\
\hline
\end{tabular}


Table B8. Data table year 2002

\begin{tabular}{l|lllll}
\hline Women's education & Men's education & & & \\
& $\begin{array}{l}\text { Primary or } \\
\text { less }\end{array}$ & $\begin{array}{l}\text { Lower } \\
\text { Secondary }\end{array}$ & $\begin{array}{l}\text { Higher } \\
\text { Secondary }\end{array}$ & Tertiary & $\begin{array}{l}\text { All women } \\
\text { (married + } \\
\text { unmarried) }\end{array}$ \\
\hline $\begin{array}{l}\text { Primary or less } \\
\text { Lower Secondary }\end{array}$ & 230 & 132 & 79 & 13 & 1112 \\
$\begin{array}{l}\text { Higher Secondary } \\
\text { Tertiary }\end{array}$ & 269 & 1376 & 902 & 119 & 4647 \\
$\begin{array}{l}\text { All men (married } \\
+ \text { unmarried) }\end{array}$ & 18967.35 & 2065 & 4645 & 1220 & 14713 \\
\hline
\end{tabular}


Table B9. Data table year 2006

\begin{tabular}{|c|c|c|c|c|c|}
\hline \multirow[t]{2}{*}{ Women's education } & \multicolumn{5}{|c|}{ Men's education } \\
\hline & $\begin{array}{l}\text { Primary or } \\
\text { less }\end{array}$ & $\begin{array}{l}\text { Lower } \\
\text { Secondary }\end{array}$ & $\begin{array}{l}\text { Higher } \\
\text { Secondary }\end{array}$ & Tertiary & $\begin{array}{l}\text { All women } \\
\text { (married + } \\
\text { unmarried) }\end{array}$ \\
\hline Primary or less & 232 & 95 & 94 & 16 & 1162 \\
\hline Lower Secondary & 192 & 973 & 729 & 110 & 3834 \\
\hline Higher Secondary & 275 & 1884 & 5374 & 1457 & 15609 \\
\hline Tertiary & 65 & 448 & 2402 & 3252 & 25450 \\
\hline $\begin{array}{l}\text { All men (married } \\
+ \text { unmarried) }\end{array}$ & 1901.27 & 6355.24 & 16055.80 & 18727.04 & 0 \\
\hline
\end{tabular}


Table B10. Data table year 2011

\begin{tabular}{|c|c|c|c|c|c|}
\hline \multirow[t]{2}{*}{ Women's education } & \multicolumn{5}{|c|}{ Men's education } \\
\hline & $\begin{array}{l}\text { Primary or } \\
\text { less }\end{array}$ & $\begin{array}{l}\text { Lower } \\
\text { Secondary }\end{array}$ & $\begin{array}{l}\text { Higher } \\
\text { Secondary }\end{array}$ & Tertiary & $\begin{array}{c}\text { All women } \\
\text { (married + } \\
\text { unmarried) }\end{array}$ \\
\hline Primary or less & 298 & 95 & 120 & 15 & 1219 \\
\hline Lower Secondary & 155 & 470 & 457 & 79 & 2497 \\
\hline Higher Secondary & 394 & 1463 & 5589 & 1367 & 15295 \\
\hline Tertiary & 109 & 485 & 3490 & 5064 & 34018 \\
\hline $\begin{array}{l}\text { All men (married } \\
+ \text { unmarried) }\end{array}$ & 2209.58 & 5104.28 & 17364.65 & 23534.46 & 0 \\
\hline
\end{tabular}


Table B11. Data table year 2016

\begin{tabular}{|c|c|c|c|c|c|}
\hline \multirow[t]{2}{*}{ Women's education } & \multicolumn{5}{|c|}{ Men's education } \\
\hline & $\begin{array}{l}\text { Primary or } \\
\text { less }\end{array}$ & $\begin{array}{l}\text { Lower } \\
\text { Secondary }\end{array}$ & $\begin{array}{l}\text { Higher } \\
\text { Secondary }\end{array}$ & Tertiary & $\begin{array}{l}\text { All women } \\
\text { (married + } \\
\text { unmarried) }\end{array}$ \\
\hline Primary or less & 278 & 70 & 128 & 25 & 1071 \\
\hline Lower Secondary & 121 & 330 & 355 & 59 & 1871 \\
\hline Higher Secondary & 281 & 964 & 4207 & 1107 & 12320 \\
\hline Tertiary & 85 & 371 & 3002 & 4848 & 32196 \\
\hline $\begin{array}{l}\text { All men (married } \\
+ \text { unmarried) }\end{array}$ & 1738.97 & 3667.34 & 14276.45 & 22961.66 & 0 \\
\hline
\end{tabular}


Table B12. Total difference in homogamy

\begin{tabular}{llllll}
\hline & 1991 & 1996 & 2002 & 2006 & 2011 \\
\hline 1991 & & & & & \\
1996 & $2.11 \%$ & & & & \\
2002 & $0.14 \%$ & $-1.97 \%$ & & & \\
2006 & $1.43 \%$ & $-0.68 \%$ & $1.29 \%$ & & \\
2011 & $3.69 \%$ & $1.58 \%$ & $3.54 \%$ & $2.26 \%$ & \\
2016 & $5.10 \%$ & $2.99 \%$ & $4.95 \%$ & $3.67 \%$ & $1.41 \%$ \\
\hline
\end{tabular}


Table B13. Difference in homogamy attributable to educational matching

\begin{tabular}{llllll}
\hline & 1991 & 1996 & 2002 & 2006 & 2011 \\
\hline 1991 & & & & & \\
1996 & $1.08 \%$ & & & & \\
2002 & $-1.11 \%$ & $-1.90 \%$ & & & \\
2006 & $-0.80 \%$ & $-1.52 \%$ & $0.16 \%$ & & \\
2011 & $-0.40 \%$ & $-0.85 \%$ & $0.99 \%$ & $1.01 \%$ & \\
2016 & $-0.10 \%$ & $-0.57 \%$ & $1.29 \%$ & $1.32 \%$ & $0.26 \%$ \\
\hline
\end{tabular}


Table B14. Difference in homogamy attributable to educational expansion

\begin{tabular}{llllll}
\hline & 1991 & 1996 & 2002 & 2006 & 2011 \\
\hline 1991 & & & & & \\
1996 & $0.92 \%$ & & & & \\
2002 & $0.94 \%$ & $-0.27 \%$ & & & \\
2006 & $1.93 \%$ & $0.66 \%$ & $1.00 \%$ & & \\
2011 & $3.33 \%$ & $1.82 \%$ & $1.95 \%$ & $0.88 \%$ & \\
2016 & $4.56 \%$ & $3.05 \%$ & $3.20 \%$ & $2.24 \%$ & $1.51 \%$ \\
\hline
\end{tabular}


Table B15. Difference in homogamy attributable to marriage gradient

\begin{tabular}{llllll}
\hline & 1991 & 1996 & 2002 & 2006 & 2011 \\
\hline 1991 & & & & & \\
1996 & $0.11 \%$ & & & & \\
2002 & $0.30 \%$ & $0.19 \%$ & & & \\
2006 & $0.29 \%$ & $0.18 \%$ & $0.13 \%$ & & \\
2011 & $0.75 \%$ & $0.60 \%$ & $0.61 \%$ & $0.37 \%$ & \\
2016 & $0.64 \%$ & $0.50 \%$ & $0.46 \%$ & $0.11 \%$ & $-0.36 \%$ \\
\hline
\end{tabular}


Table B16. Total difference in female hypogamy

\begin{tabular}{llllll}
\hline & 1991 & 1996 & 2002 & 2006 & 2011 \\
\hline 1991 & & & & & \\
1996 & $-1.00 \%$ & & & & \\
2002 & $2.54 \%$ & $3.54 \%$ & & & \\
2006 & $3.40 \%$ & $4.40 \%$ & $0.86 \%$ & & \\
2011 & $4.50 \%$ & $5.50 \%$ & $1.96 \%$ & $1.10 \%$ & \\
2016 & $3.20 \%$ & $4.19 \%$ & $0.66 \%$ & $-0.20 \%$ & $-1.30 \%$ \\
\hline
\end{tabular}


Table B17. Difference in female hypogamy attributable to educational matching

\begin{tabular}{llllll}
\hline & 1991 & 1996 & 2002 & 2006 & 2011 \\
\hline 1991 & & & & & \\
1996 & $-0.55 \%$ & & & & \\
2002 & $0.75 \%$ & $1.12 \%$ & & & \\
2006 & $0.67 \%$ & $0.98 \%$ & $-0.06 \%$ & & \\
2011 & $0.48 \%$ & $0.64 \%$ & $-0.42 \%$ & $-0.44 \%$ & \\
2016 & $0.45 \%$ & $0.59 \%$ & $-0.51 \%$ & $-0.54 \%$ & $-0.07 \%$ \\
\hline
\end{tabular}


Table B18. Difference in female hypogamy attributable to educational expansion

\begin{tabular}{llllll}
\hline & 1991 & 1996 & 2002 & 2006 & 2011 \\
\hline 1991 & & & & & \\
1996 & $-0.86 \%$ & & & & \\
2002 & $1.08 \%$ & $1.85 \%$ & & & \\
2006 & $1.39 \%$ & $2.24 \%$ & $0.49 \%$ & & \\
2011 & $2.99 \%$ & $3.83 \%$ & $1.95 \%$ & $1.34 \%$ & \\
2016 & $1.83 \%$ & $2.60 \%$ & $0.55 \%$ & $-0.21 \%$ & $-1.70 \%$ \\
\hline
\end{tabular}


Table B19. Difference in female hypogamy attributable to marriage gradient

\begin{tabular}{llllll}
\hline & 1991 & 1996 & 2002 & 2006 & 2011 \\
\hline 1991 & & & & & \\
1996 & $0.41 \%$ & & & & \\
2002 & $0.71 \%$ & $0.56 \%$ & & & \\
2006 & $1.33 \%$ & $1.18 \%$ & $0.43 \%$ & & \\
2011 & $1.03 \%$ & $1.03 \%$ & $0.43 \%$ & $0.19 \%$ & \\
2016 & $0.91 \%$ & $1.01 \%$ & $0.63 \%$ & $0.55 \%$ & $0.47 \%$ \\
\hline
\end{tabular}


Table B20. Total difference in female hypergamy

\begin{tabular}{llllll}
\hline & 1991 & 1996 & 2002 & 2006 & 2011 \\
\hline 1991 & & & & & \\
1996 & $-1.11 \%$ & & & & \\
2002 & $-2.68 \%$ & $-1.57 \%$ & & & \\
2006 & $-4.83 \%$ & $-3.71 \%$ & $-2.15 \%$ & & \\
2011 & $-8.18 \%$ & $-7.07 \%$ & $-5.50 \%$ & $-3.36 \%$ & \\
2016 & $-8.29 \%$ & $-7.18 \%$ & $-5.61 \%$ & $-3.47 \%$ & $-0.11 \%$ \\
\hline
\end{tabular}


Table B21. Difference in female hypergamy attributable to educational matching

\begin{tabular}{llllll}
\hline & 1991 & 1996 & 2002 & 2006 & 2011 \\
\hline 1991 & & & & & \\
1996 & $-0.53 \%$ & & & & \\
2002 & $0.36 \%$ & $0.77 \%$ & & & \\
2006 & $0.12 \%$ & $0.55 \%$ & $-0.10 \%$ & & \\
2011 & $-0.09 \%$ & $0.21 \%$ & $-0.57 \%$ & $-0.57 \%$ & \\
2016 & $-0.36 \%$ & $-0.02 \%$ & $-0.78 \%$ & $-0.78 \%$ & $-0.19 \%$ \\
\hline
\end{tabular}


Table B22. Difference in female hypergamy attributable to educational expansion

\begin{tabular}{llllll}
\hline & 1991 & 1996 & 2002 & 2006 & 2011 \\
\hline 1991 & & & & & \\
1996 & $-0.06 \%$ & & & & \\
2002 & $-2.02 \%$ & $-1.58 \%$ & & & \\
2006 & $-3.33 \%$ & $-2.90 \%$ & $-1.49 \%$ & & \\
2011 & $-6.32 \%$ & $-5.65 \%$ & $-3.90 \%$ & $-2.22 \%$ & \\
2016 & $-6.39 \%$ & $-5.65 \%$ & $-3.75 \%$ & $-2.03 \%$ & $0.20 \%$ \\
\hline
\end{tabular}


Table B23. Difference in female hypergamy attributable to marriage gradient

\begin{tabular}{llllll}
\hline & 1991 & 1996 & 2002 & 2006 & 2011 \\
\hline 1991 & & & & & \\
1996 & $-0.52 \%$ & & & & \\
2002 & $-1.01 \%$ & $-0.76 \%$ & & & \\
2006 & $-1.62 \%$ & $-1.36 \%$ & $-0.56 \%$ & & \\
2011 & $-1.77 \%$ & $-1.62 \%$ & $-1.04 \%$ & $-0.56 \%$ & \\
2016 & $-1.54 \%$ & $-1.51 \%$ & $-1.09 \%$ & $-0.66 \%$ & $-0.12 \%$ \\
\hline
\end{tabular}




\section{Numerical Example}

\section{Marriage Table and Marriage Outcomes}

We illustrate the methodology by decomposing the difference in marriage outcomes between 1991 and 2016. Matrix $\boldsymbol{M}_{1991}$ contains the relative joint distribution of wives' and their husbands' education in 1991 and $\boldsymbol{M}_{2016}$ in 2016, respectively.

$\boldsymbol{M}_{1991}=\left[\begin{array}{llll}.063 & .030 & .020 & .001 \\ .043 & .159 & .082 & .006 \\ .037 & .136 & .274 & .052 \\ .002 & .010 & .037 & .048\end{array}\right]$

$$
\boldsymbol{M}_{2016}=\left[\begin{array}{llll}
.017 & .004 & .008 & .002 \\
.007 & .020 & .022 & .004 \\
.017 & .059 & .259 & .068 \\
.005 & .023 & .185 & .299
\end{array}\right]
$$

The marriage outcome $Y$ at time $t$ is a scalar function of $\boldsymbol{M}_{t}$ :

$$
Y_{t}=f\left(\boldsymbol{M}_{t}\right)
$$

For example, the probability of homogamy (spouses have the same education) in 1991 is the sum over the diagonal of $\boldsymbol{M}_{1991}$ : 


$$
Y^{W=H}\left(\boldsymbol{M}_{1991}\right)=.063+.159+.274+.048=.544
$$

Accordingly, the probability of female hypergamy (wives married upward) is the sum of the upper off-diagonals

$$
Y^{W<H}\left(\boldsymbol{M}_{1991}\right)=.030+.020+.001+.082+.006+.052=.191
$$

and the probability of female hypogamy (wives married downward) is the sum of the lower off-diagonals

$$
Y^{W>H}\left(\boldsymbol{M}_{1991}\right)=.043+.037+.136+.002+.010+.037=.265
$$

\section{Dissecting the Marriage Table}

Wives' educational distribution is given by the row sum of $\boldsymbol{M}_{1991}$ and husbands' distribution by the column sum:

$$
\boldsymbol{E}_{1991}^{W}=\left[\begin{array}{l}
.113 \\
.291 \\
.499 \\
.097
\end{array}\right], \boldsymbol{E}_{1991}^{H}=\left[\begin{array}{lll}
.145 & .335 & .413 .107
\end{array}\right]
$$

The odds ratio matrix shows the association structure within the table. Below, we show the odds ratio matrix for the marriage table from 1991. As a convention, we show odds ratios relative to first row and column (therefore we see ones in those rows). 


$$
\boldsymbol{O} \boldsymbol{R}_{1991}=\left[\begin{array}{cccc}
1 & 1 & 1 & 1 \\
1 & 7.68 & 6.06 & 12.04 \\
1 & 7.74 & 23.91 & 116.00 \\
1 & 8.82 & 50.23 & 1685.01
\end{array}\right]
$$

For example, the odds of wives with tertiary education $(i=4)$ of marrying a man with higher secondary education $(j=3)$ rather than primary education $(j=1$, first column as reference category for the odds) are $\frac{.037}{.002}=18.5$. In other words, highly educated wives are 18.5 times more likely to be married to a higher secondary educated husband than to a primary level educated husband. The corresponding odds for primary level educated wives ( $i=1$, first row as reference category for the odds ratio) are $\frac{.020}{.063}=$ .317. Correspondingly, the odds ratio is $\frac{18.5}{.317}=58.3$ (due to rounding issues a bit higher than the 50.23 shown in the table above).

The IPF function $\boldsymbol{M}_{1991}$ takes the odds-ratio matrix and row and column totals to fit the table's cells.

$$
\boldsymbol{M}_{1991} \underset{x \rightarrow \infty}{=} M\left(\boldsymbol{E}_{1991}^{W}, \boldsymbol{E}_{1991}^{H}, \boldsymbol{O} \boldsymbol{R}_{1991}\right)
$$

In the same way, the marriage table in $2016\left(\boldsymbol{M}_{2016}\right)$ can be dissected in row $\left(\boldsymbol{E}_{2016}^{W}\right)$ and column totals $\left(\boldsymbol{E}_{2016}^{H}\right)$ and an odds ratio matrix $\left(\boldsymbol{O} \boldsymbol{R}_{2016}\right)$.

\section{Two-Fold Decomposition: Opportunities and Matching}

Both mechanisms, two-sided matching preferences, and marriage opportunities shape marriage outcomes, but both have changed from 1991 to 2016. Based on the IPF function 
from above, counterfactuals are defined as hypothetical tables that we would observe if opportunities and matching preferences were swapped:

$$
\dot{Y}_{2016,1991}=Y\left(\boldsymbol{M}_{t}\left(\boldsymbol{E}_{2016}^{W}, \boldsymbol{E}_{2016}^{H}, \boldsymbol{O} \boldsymbol{R}_{1991}\right)\right)=.603
$$

and

$$
\dot{Y}_{1991,2016}=Y\left(\boldsymbol{M}_{t}\left(\boldsymbol{E}_{1991}^{W}, \boldsymbol{E}_{1991}^{H}, \boldsymbol{O} \boldsymbol{R}_{2016}\right)\right)=.550
$$

The overall difference in homogamy between 2016 and 1991 can be written as

$$
.595-.544=(.595-.550)+(.550-.544)
$$

In the same fashion, we could write

$$
.595-.544=(.603-.544)+(.595-.603)
$$

Adding both equations and rearranging terms leads to

$$
\begin{aligned}
.595-.544 & =\frac{1}{2}(.595-.550+.603-.544) \\
& +\frac{1}{2}(.550-.544+.595-.603)
\end{aligned}
$$


The first term of the equation $\left(\frac{1}{2}(.595-.550+.603-.544)=.052\right)$ expresses the opportunity effect and the second term $\left(\frac{1}{2}(.550-.544+.595-.603)=-.001\right)$ the 'choice' or preference effect.

\section{Three-Fold Decomposition: Education Expansion and Changing Marriage}

\section{Gradient}

Formally, wives' relative education distributions are the product of women's education distribution and women's education-specific probabilities of being married (marriage rates):

$$
\boldsymbol{E}_{1991}^{W}=\boldsymbol{G}_{1991}^{F} \boldsymbol{E}_{1991}^{F} \cdot \frac{1}{\operatorname{SUM}\left(\boldsymbol{G}_{1991}^{F} \boldsymbol{E}_{1991}^{F}\right)}
$$

Based on the marriage table from 1991 (see Table B6), women's education distribution is given by

$$
\boldsymbol{E}_{1991}^{F}=\left[\begin{array}{c}
2655 \\
6074 \\
12214 \\
5922
\end{array}\right]
$$

The marriage gradient is expressed by the probability of being married which may vary by educational level. For example, based on marriage table 1991 (see Table B6) the probability of being married for women with lower secondary education is calculated by $\frac{683+2510+1292+100}{6074}=.755$. Education-specific probabilities are fed into a diagonal matrix 
$\boldsymbol{G}_{\mathbf{1 9 9 1}}^{\boldsymbol{F}}$ with elements $g_{i i}$ denoting the probabilities of being married for women with education level $i$.

$$
\boldsymbol{G}_{\mathbf{1 9 9 1}}^{\boldsymbol{F}}=\left[\begin{array}{cccc}
.670 & 0 & 0 & 0 \\
0 & .755 & 0 & 0 \\
0 & 0 & .645 & 0 \\
0 & 0 & 0 & .259
\end{array}\right]
$$

The number of women married by educational level is given by the matrix product. The sum of the product matrix is

$$
\operatorname{SUM}\left(\boldsymbol{G}_{t}^{F} \boldsymbol{E}_{t}^{F}\right)=15767
$$

Finally, we obtain wives' relative education distribution by dividing the product matrix by its sum:

$$
\boldsymbol{E}_{1991}^{W}=\left[\begin{array}{l}
1779 \\
4585 \\
7872 \\
1531
\end{array}\right] \cdot \frac{1}{15767}=\left[\begin{array}{l}
.113 \\
.291 \\
.499 \\
.097
\end{array}\right]
$$

Based on that, we redefine the marriage table $t$ as a function of five components

$$
\boldsymbol{M}_{t}=M\left[E\left(\boldsymbol{G}_{t}^{F}, \boldsymbol{E}_{t}^{F}\right), E\left(\boldsymbol{G}_{t}^{M}, \boldsymbol{E}_{t}^{M}\right), \boldsymbol{O} \boldsymbol{R}_{t}\right]
$$


We construct $2^{3}=8$ factual and counterfactual marriage outcomes (Equations C 21 C 28), distinguishing between education distributions (in the population of men and women), the marriage gradients, and matching preferences.

$$
\begin{aligned}
Y_{1991,1991,1991} & =Y\left(M\left[E\left(\boldsymbol{G}_{1991}^{F}, \boldsymbol{E}_{1991}^{F}\right), E\left(\boldsymbol{G}_{1991}^{M}, \boldsymbol{E}_{1991}^{M}\right), \boldsymbol{O} \boldsymbol{R}_{1991}\right]\right) \\
& =.544
\end{aligned}
$$

$$
\begin{aligned}
\dot{Y}_{2016,1991,1991} & =Y\left(M\left[E\left(\boldsymbol{G}_{2016}^{F}, \boldsymbol{E}_{1991}^{F}\right), E\left(\boldsymbol{G}_{2016}^{M}, \boldsymbol{E}_{1991}^{M}\right), \boldsymbol{O} \boldsymbol{R}_{1991}\right]\right) \\
& =.551
\end{aligned}
$$

$$
\begin{aligned}
\dot{Y}_{1991,2016,1991} & =Y\left(M\left[E\left(\boldsymbol{G}_{1991}^{F}, \boldsymbol{E}_{2016}^{F}\right), E\left(\boldsymbol{G}_{1991}^{M}, \boldsymbol{E}_{2016}^{M}\right), \boldsymbol{O} \boldsymbol{R}_{1991}\right]\right) \\
& =.596
\end{aligned}
$$

$$
\begin{aligned}
\dot{Y}_{2016,2016,1991} & =Y\left(M\left[E\left(\boldsymbol{G}_{2016}^{F}, \boldsymbol{E}_{2016}^{F}\right), E\left(\boldsymbol{G}_{2016}^{M}, \boldsymbol{E}_{2016}^{M}\right), \boldsymbol{O} \boldsymbol{R}_{1991}\right]\right) \\
& =.603
\end{aligned}
$$

$$
\begin{aligned}
Y_{1991,1991,2016} & =Y\left(M\left[E\left(\boldsymbol{G}_{1991}^{F}, \boldsymbol{E}_{1991}^{F}\right), E\left(\boldsymbol{G}_{1991}^{M}, \boldsymbol{E}_{1991}^{M}\right), \boldsymbol{O} \boldsymbol{R}_{2016}\right]\right) \\
& =.550
\end{aligned}
$$




$$
\begin{aligned}
\dot{Y}_{2016,1991,2016} & =Y\left(M\left[E\left(\boldsymbol{G}_{2016}^{F}, \boldsymbol{E}_{1991}^{F}\right), E\left(\boldsymbol{G}_{2016}^{M}, \boldsymbol{E}_{1991}^{M}\right), \boldsymbol{O} \boldsymbol{R}_{2016}\right]\right) \\
& =.555 \\
\dot{Y}_{1991,2016,2016} & =Y\left(M\left[E\left(\boldsymbol{G}_{1991}^{F}, \boldsymbol{E}_{2016}^{F}\right), E\left(\boldsymbol{G}_{1991}^{M}, \boldsymbol{E}_{2016}^{M}\right), \boldsymbol{O} \boldsymbol{R}_{2016}\right]\right) \\
& =.589 \\
\dot{Y}_{2016,2016,2016} & =Y\left(M\left[E\left(\boldsymbol{G}_{2016}^{F}, \boldsymbol{E}_{2016}^{F}\right), E\left(\boldsymbol{G}_{2016}^{M}, \boldsymbol{E}_{2016}^{M}\right), \boldsymbol{O} \boldsymbol{R}_{2016}\right]\right) \\
& =.595
\end{aligned}
$$

We can write the difference in marriage outcomes in 1991 and 2016 as the sum of the average opportunity and preferences effect:

$$
\begin{aligned}
.595-.544= & \frac{1}{2}(.595-.550+.603-.544)+\frac{1}{2}(.550-.544 \\
& +.595-.603)
\end{aligned}
$$

Now, the opportunity effects can be further disentangled into an 'educational expansion' effect and a 'marriage gradient' effect. The first part of the opportunity effect is

$$
\begin{aligned}
.595-.544= & \underbrace{\frac{1}{2}(.595-.555+.589-.550)}_{\text {educational expansion }} \\
& +\underbrace{\frac{1}{2}(.555-.550+.595-.589)}_{\text {marriage gradient }}
\end{aligned}
$$


Accordingly, the second part is

$$
\begin{aligned}
.595-.544= & \underbrace{\frac{1}{2}(.603-.551+.596-.544)}_{\text {educational expansion }} \\
& +\underbrace{\frac{1}{2}(.551-.544+.603-.596)}_{\text {marriage gradient }}
\end{aligned}
$$

Hence, the overall opportunity effect is composed of two sub-components, the average educational expansion effect and the average marriage gradient effect.

$$
\begin{aligned}
& \Delta^{O}=\underbrace{\frac{1}{2}(.595-.550+.603-.544)}_{\text {Opportunity }} \\
& =\underbrace{\frac{1}{4}(.595-.555+.589-.550+.603-.551+.596-.544)}_{\text {educational expansion } \Delta^{E}} \\
& +\underbrace{\frac{1}{4}(.555-.550+.595-.589+.551-.544+.603-.596)}_{\text {marriage gradient } \Delta^{G}}
\end{aligned}
$$

